\title{
Long-Delayed Expression of the Immediate Early Gene Arc/ Arg3.1 Refines Neuronal Circuits to Perpetuate Fear Memory
}

\author{
Daisuke Nakayama, ${ }^{1}$ Hirokazu Iwata, ${ }^{1}$ Chie Teshirogi, ${ }^{1}$ Yuji Ikegaya, ${ }^{1,2}$ Norio Matsuki, ${ }^{1}$ and Hiroshi Nomura ${ }^{1}$ \\ ${ }^{1}$ Laboratory of Chemical Pharmacology, Graduate School of Pharmaceutical Sciences, The University of Tokyo, Tokyo 113-0033, Japan, and ${ }^{2}$ Center for \\ Information and Neural Networks, Suita City, Osaka 565-0871, Japan
}

Fear memories typically persist for long time periods, and persistent fear memories contribute to post-traumatic stress disorder. However, little is known about the cellular and synaptic mechanisms that perpetuate long-term memories. Here, we find that mouse hippocampal CA1 neurons exhibit biphasic Arc (also known as Arg3.1) elevations after fear experience and that the late Arc expression regulates the perpetuation of fear memoires. An early Arc increase returned to the baseline after $6 \mathrm{~h}$, followed by a second Arc increase after $12 \mathrm{~h}$ in the same neuronal subpopulation; these elevations occurred via distinct mechanisms. Antisense-induced blockade of late Arc expression disrupted memory persistence but not formation. Moreover, prolonged fear memories were associated with the delayed, specific elimination of dendritic spines and the reactivation of neuronal ensembles formed during fear experience, both of which required late Arc expression. We propose that late Arc expression refines functional circuits in a delayed fashion to prolong fear memory.

Key words: Arc/Arg3.1; BDNF; dendritic spines; fear conditioning; hippocampus; memory engram

\section{Introduction}

Fear memories typically persist for long time periods, and persistent fear memories may contribute to post-traumatic stress disorder (Steckler and Risbrough, 2012). Formation of long-term fear memory depends on rapid molecular cascades followed by the induction of synaptic plasticity (Johansen et al., 2011); however, the cellular and synaptic mechanisms that perpetuate longterm memories are less understood. A recent study found that inhibition of protein synthesis $12 \mathrm{~h}$ after learning impaired longterm memory retention at $7 \mathrm{~d}$ but not $2 \mathrm{~d}$ after learning (Bekinschtein et al., 2007), implicating late biochemical changes in memory persistence. Therefore, it is possible that perpetuation of long-term memories is associated with unique cellular mechanisms that require late biochemical changes.

$\operatorname{Arc}$ (also known as Arg3.1) is an immediate early gene that is required for the consolidation of synaptic plasticity and longterm memory (Guzowski et al., 2000; Plath et al., 2006). Late Arc expression after spatial exploration has been reported (RamírezAmaya et al., 2005), although its relationship with learning as well

Received June 19, 2014; revised Oct. 14, 2014; accepted Nov. 21, 2014.

Author contributions: Y.I., N.M., and H.N. designed research; D.N., H.I., and C.T. performed research; D.N., H.I., and H.N. analyzed data; D.N. and H.N. wrote the paper.

This work was supported by a Grant-in-Aid for Young Scientists (B) 25830002 to H.N., Grant-in-Aid for Scientific Research on Innovative Areas, "Memory Dynamism" 26115509 to H.N., "The Science of Mental Time" 26119507 to H.N. and 25119004 to Y.I., and "Mesoscopic Neurocircuitry" 23115101 to H.N. We thank Dr. Vincenzo de Paola (Imperial College London) and Dr. Pico Caroni (Friedrich Miescher Institute) for supplying Thy1-mGFP transgenic mice; Dr. Takuma Kitanishi (Kyoto University) for technical advice in spine analysis; and the University of Tokyo/Leica microsystems imaging center for obtaining the imaging data.

The authors declare no competing financial interests.

Correspondence should be addressed to Dr. Hiroshi Nomura, Laboratory of Chemical Pharmacology, Graduate School of Pharmaceutical Sciences, University of Tokyo, 7-3-1 Hongo, Bunkyo-ku, Tokyo 113-0033, Japan. E-mail: nomura@mol.f.u-tokyo.ac.jp.

DOI:10.1523/JNEUROSCI.2525-14.2015

Copyright $\odot 2015$ the authors $\quad 0270-6474 / 15 / 350819-12 \$ 15.00 / 0$ as its role and induction mechanisms have not been examined. Previous studies have revealed that Arc is central for synaptic scaling in vitro (Shepherd et al., 2006) and for synapse elimination during visual cortex and cerebellum maturation in vivo (Gao et al., 2010; McCurry et al., 2010; Mikuni et al., 2013). Although developing neural circuits prune synapses to shape synaptic connectivity, in the mature brain, experience and associative learning can also lead to synapse elimination (Yang et al., 2009; Hübener and Bonhoeffer, 2010; Lai et al., 2012; Sanders et al., 2012). Particularly, spine elimination in the late phase after learning has been proposed to be a mechanism for the long-term stabilization of memory (Grønli et al., 2013). This spine elimination, which could enhance signal-to-noise ratios to encode experiencedriven information (Grønli et al., 2013; Schacher and Hu, 2014), may later lead to stable reactivation of neuronal ensembles bearing a memory engram.

In this study, we examined Arc expression early and late after associative learning and identified their roles in memory and refinement of neuronal circuits. We measured hippocampal Arc levels at multiple time points after contextual fear conditioning (FC) and discovered that Arc expression increases not only immediately but also $12 \mathrm{~h}$ after conditioning. Using an antisense oligodeoxynucleotide (ODN) approach, we selectively blocked late Arc expression and found that late Arc expression is required for persistence, but not formation, of contextual fear memory. Furthermore, with Thy1-mGFP and Fos-H2BGFP mice, we assessed structural modifications associated with memory persistence. Memory persistence was associated with spine elimination and the reactivation of neuronal ensembles formed during learning, and late Arc expression was critically involved in these processes. Our findings provide novel insight into the cellular and synaptic mechanisms underlying memory persistence. 


\section{Materials and Methods}

Mice. All experiments were approved by the animal experiment ethics committee at the University of Tokyo (approval number 24-10) and were in accordance with the University of Tokyo guidelines for the care and use of laboratory animals.

Adult male C57BL/6J mice (Japan SLC), Fos-H2BGFP mice, and Thy1-mGFP mice, weighing 20-30 g and 8-13 weeks of age, were housed 2-4 per cage and kept on a $12 \mathrm{~h}$ light/dark cycle (lights on from 7:00 A.M. to 7:00 P.M.). Fos-H2BGFP mice (Tayler et al., 2013) were generated by crossing hemizygous transgenic mice that express tetracyclinetransactivator (tTA) under control of the $c$-Fos promoter (strain, $\mathrm{Tg}$ (FostTA,Fos-EGFP ${ }^{*}$ 1Mmay; stock \#008344; The Jackson Laboratory) (Reijmers et al., 2007) with hemizygous transgenic mice that express a H2B-GFP fusion protein under control of tetO (strain, Tg(tetOHIST1H2BJ/GFP)47Efu/J; stock \#005104; The Jackson Laboratory). Mice were raised on food containing doxycycline (Dox) $(40 \mathrm{mg} / \mathrm{kg}$ ) before behavioral experiments. When the rapid inhibition of H2B-GFP expression was required after behavioral tasks, the mice were given food containing $1 \mathrm{~g} / \mathrm{kg}$ Dox. Dendritic spine morphology was observed with Thy1-mGFP mice (line 21, gift from Drs. V. de Paola and P. Caroni) (De Paola et al., 2003), which express membrane-targeted EGFP in a small number of neurons. Transgenic mice were maintained on a C57BL/6J background. All mice were given free access to food and water and acclimated to daily handling for 1 week before the start of the study.

Behavioral procedures. Contextual FC and subsequent testing were performed in a conditioning chamber $(18 \mathrm{~cm}$ wide, $15 \mathrm{~cm}$ deep, and 27 $\mathrm{cm}$ high) that had a stainless steel grid floor (Nomura et al., 2012). The chamber was cleaned with $70 \%$ ethanol before each session. A conditioning session consisted of placing the mice in the chamber and delivering a $2 \mathrm{~s}$ footshock $(1 \mathrm{~mA})$ after $148 \mathrm{~s}$. The mice then received 2 additional shocks every $148 \mathrm{~s}$. They were kept in the chamber for an additional $60 \mathrm{~s}$ and were then returned to their home cages. An immediate shock (IS) session consisted of delivering $2 \mathrm{~s}$ footshocks 3 times to the mice immediately after placing them in the chamber. The mice then remained in the chamber for $500 \mathrm{~s}$. The testing session consisted of exposing the mice to the conditioning chamber for $5 \mathrm{~min}$ in the absence of a footshock. A neutral context session consisted of exposing the mice to another chamber (47 cm wide, $47 \mathrm{~cm}$ high, and $20 \mathrm{~cm}$ deep) for $10 \mathrm{~min}$. All sessions were performed between 8:00 A.M. and 12:00 P.M., and each session was video-recorded for automatic scoring of freezing, according to a previously described method (Nomura and Matsuki, 2008). Fear memory was assessed and expressed as the percentage of time the animal remained frozen, a commonly used parameter for measuring conditioned fear in mice. Freezing was defined as the absence of all movements, except those related to breathing.

Western blotting. Mice were decapitated after diethyl ether anesthesia, and their brains were rapidly removed and frozen at $-80^{\circ} \mathrm{C}$. Coronal brain sections $(300 \mu \mathrm{m})$ were prepared using a cryostat (HM520; Thermo Fisher Scientific). The dorsal hippocampus (1.30-1.90 mm posterior to bregma) was punched out and homogenized in RIPA buffer (08714-04, Nacalai Tesque). Protein concentrations were normalized across homogenates using the BCA method (Thermo Fisher Scientific). Equal amounts of protein were electrophoresed on 5\%-20\% SDS polyacrylamide gels and transferred to nitrocellulose membranes. Western blots were blocked in blocking buffer (03953-95, Nacalai Tesque) and then incubated with an anti-Arc/Arg3.1 antibody (sc-17839, Santa Cruz Biotechnology) at a 1:1000 dilution or with an anti- $\beta$-actin antibody (A3854, Sigma) at a 1:10,000 dilution. After incubation with anti-mouse IgG (A9044, Sigma) at a 1:100,000 dilution, bands were developed with a chemiluminescent substrate (RPN2132, GE Healthcare). The immunopositive signals were quantified by ImageQuant LAS 4000 (GE Healthcare). Arc/Arg3.1 signals were normalized with $\beta$-actin signals.

Immunohistochemistry. After anesthesia with diethyl ether, mice were transcardially perfused with PBS followed by $4 \%$ PFA. Brains were postfixed in $4 \%$ PFA for $12 \mathrm{~h}$. Free-floating coronal sections $(40 \mu \mathrm{m})$ were prepared using a cryostat. Arc was visualized with an anti-Arc/Arg3.1 primary antibody (156 003, 1:1000; Synaptic Systems), biotinylated antirabbit secondary antibody (BA-1000, 1:500; Vector Laboratories), VEC-
TASTAIN ABC Kit (Vector Laboratories), and TSA Plus Cyanine 3 System (NEL744001KT, 1:100; PerkinElmer). H2B-GFP protein was visualized with an anti-green fluorescent protein primary antibody (A11120, 1:1000; Invitrogen) and AlexaFluor-488 goat anti-mouse IgG secondary antibody (A-11001, 1:1000; Invitrogen). Nuclei were counterstained with Hoechst dye (1:1000; Invitrogen). NeuN was visualized with an anti-NeuN primary antibody (MAB377, 1:1000; Merck Millipore), and AlexaFluor-488 goat anti-mouse IgG secondary antibody. GFAP was visualized with anti-GFAP primary antibody (G9269, 1:1000; Sigma) and AlexaFluor-594 goat anti-rabbit IgG secondary antibody (A11037, 1:1000; Invitrogen). Iba1 was visualized with anti-Iba1 primary antibody (019-19741, 1:1000; Wako) and AlexaFluor-594 goat anti-rabbit IgG secondary antibody (A11037, 1:1000; Invitrogen).

Confocal microscopy and image analysis following immunohistochemistry. Images of hippocampal CA1, CA3, and DG neurons $(1.30-1.90 \mathrm{~mm}$ posterior to bregma, $4-6$ slices per mouse) were acquired using a confocal microscope (CV1000; YOKOGAWA) at $40 \times$ under an oilimmersion lens (NA, 1.3). Areas of analysis were $z$-sectioned in $1.6 \mu \mathrm{m}$ optical sections. The same laser and scanning settings were used for images within an experiment to allow for comparison across groups. Fluorescence images were analyzed using ImageJ software (National Institutes of Health). The nuclei in the CA1 pyramidal layer were traced in the Hoechst channel using ImageJ software. Only cells that were presumptive neurons, with large nuclei stained diffusely with Hoechst, were included in the analysis. The traced regions were copied to corresponding Arc and GFP channels for analysis. The designation "H2B-GFPpositive $\left(\mathrm{H} 2 \mathrm{~B}-\mathrm{GFP}^{+}\right)$" was assigned to cells whose nuclei were entirely labeled with GFP. The designation "Arc-positive $\left(\mathrm{Arc}^{+}\right)$," "NeuNpositive $\left(\mathrm{NeuN}^{+}\right)$," and "Ibal-positive $\left(\mathrm{Ibal}^{+}\right)$" were assigned to cells containing perinuclear labeling over multiple optical sections. Averaged GFAP fluorescence intensity per pixel in the CA1 region was quantified using ImageJ software. To obtain relative Arc ratio of $\mathrm{GFP}^{+}$or $\mathrm{GFP}^{-}$ neurons, we divided the proportion of neurons with Arc signal in GFP ${ }^{+}$ or $\mathrm{GFP}^{-}$neurons by the proportion of neurons with Arc signal in all neurons. An experimenter blind to behavioral condition assigned labels for H2B-GFP and Arc independently and counted the number of $\mathrm{NeuN}^{+}$and Ibal ${ }^{+}$neurons.

Surgery. Mice were anesthetized with pentobarbital $(2.5 \mathrm{mg} / \mathrm{kg}$, i.p.) and xylazine $(10 \mathrm{mg} / \mathrm{kg}$, i.p.), and 26 -gauge stainless-steel guide cannulae (Plastics One) were implanted in the dorsal hippocampus $(-2.0, \pm 1.7$, -1.5 relative to bregma). Cannulae were secured to the skull using a mixture of acrylic and dental cement, and 33-gauge dummy cannulae were then inserted into each guide cannula to prevent clogging. Mice were given at least $7 \mathrm{~d}$ of postoperative recovery time.

ODN design. Arc/Arg3.1 antisense ODN and scrambled ODN were designed in reference to a previous study (Guzowski et al., 2000). The Arc/Arg3.1 ODN encoded an antisense sequence for the Arc/Arg3.1 mRNA sequence near the translation start site (Lyford et al., 1995). The scrambled ODN did not show significant homology to any sequences in the GenBank database (Guzowski et al., 2000). Both ODNs contained phosphorothioate linkages on the three terminal bases of both the $5^{\prime}$ and $3^{\prime}$ ends and phosphodiester internal bonds. This design is reported as more stable than unmodified phosphorothioated ODNs in vivo and less toxic than fully phosphorothioated ODNs (Guzowski et al., 2000). The following sequences were used (“ " denotes a phosphorothioate linkage): $\quad 5^{\prime}-\mathrm{G} \sim \mathrm{T} \sim \mathrm{C} \sim \mathrm{CAGCTCCATCTGGT} \sim \mathrm{C} \sim \mathrm{G} \sim \mathrm{T}-3^{\prime} \quad$ (antisense)

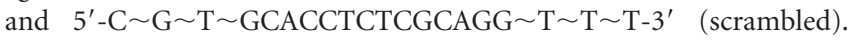
This antisense sequence has been shown to effectively inhibit Arc/Arg3.1 protein expression in the hippocampus and to exhibit a high degree of specificity for Arc relative to other immediate early genes (Guzowski et al., 2000; Onoue et al., 2014).

Drugs and microinfusions. Mice received intrahippocampal infusion ( $0.5 \mu$ l per side) of ODN ( $400 \mathrm{pmol})$, TTX ( $0.5 \mathrm{ng}$, Tocris Bioscience), or function-blocking antibody to BDNF $(0.31 \mu \mathrm{g}$, Millipore). The solutions were dissolved in PBS or saline, and PBS, saline, or IgG $(0.31 \mu \mathrm{g}$, Millipore) was used as vehicle solution. Infusions were made over $2 \mathrm{~min}$, and the infusion cannulae ( 28 gauge, extending $0.5 \mathrm{~mm}$ below the guide cannula) were left in place for at least $2 \mathrm{~min}$ afterward to facilitate the diffusion of solutions throughout the whole dorsal hippocampus. 
A

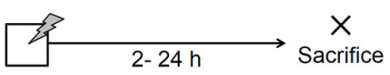

B
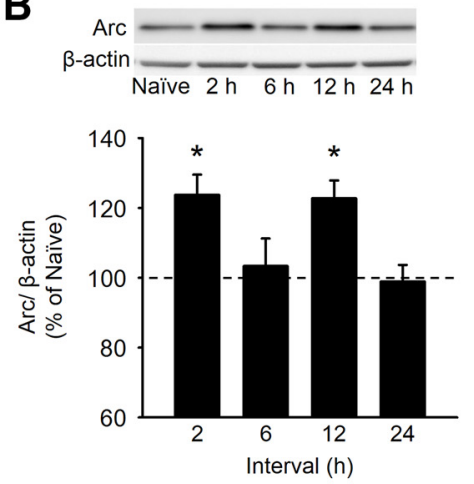

G

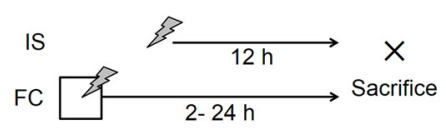

I

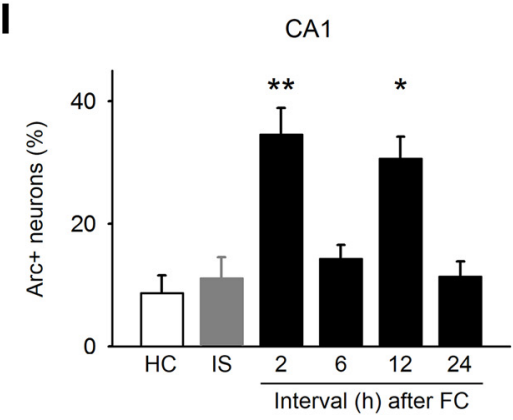

C

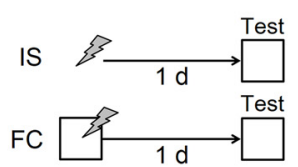

D

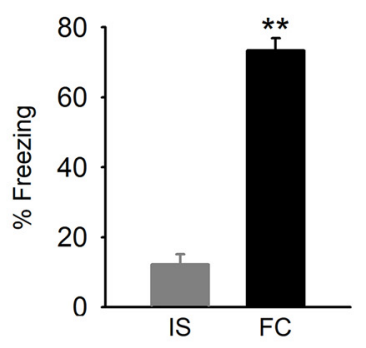

H

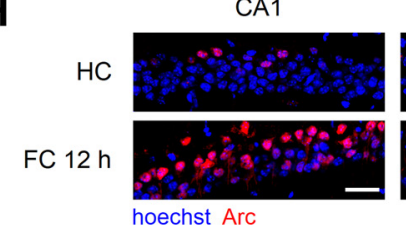

CA3

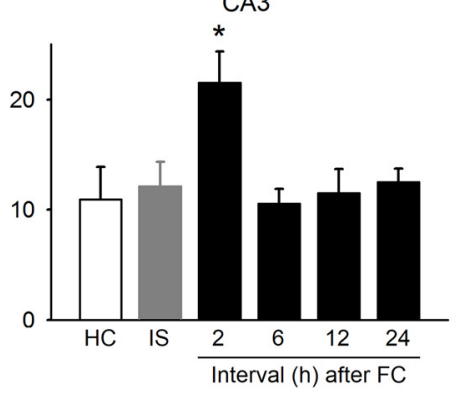

F
E

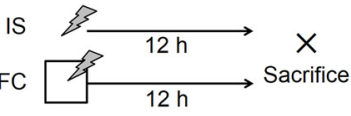

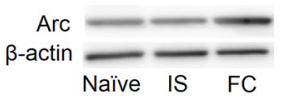
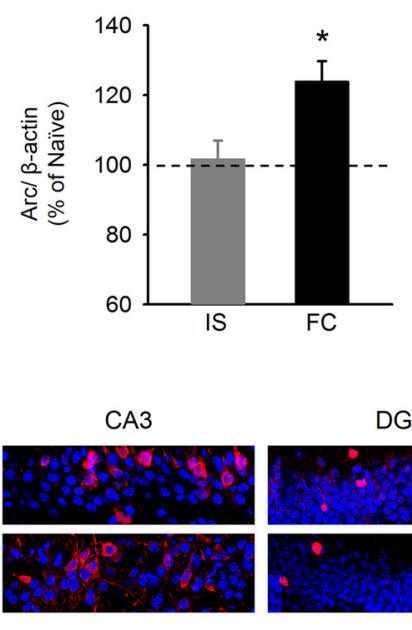

DG

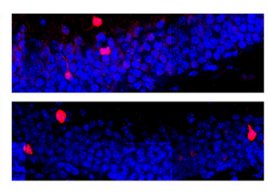

DG

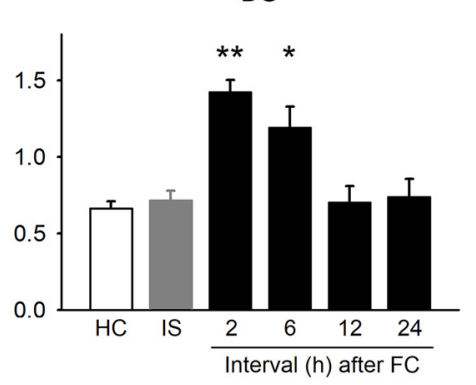

Figure 1. Early and late Arc expression after contextual FC. $A$, Mice were killed 2, 6, 12, or $24 \mathrm{~h}$ after contextual FC. B, Hippocampal Arc expression was upregulated 2 and $12 \mathrm{~h}$ but not 6 and $24 \mathrm{~h}$ after FC ( $n=10$ mice per group). C, D, Mice that were subjected to contextual FC ( $F($ group) showed longer freezing behavior in the memory test than mice that received IS ( $n=6$ mice per group). E, Mice were killed $12 \mathrm{~h}$ after FC or IS. F, FC group showed greater Arc level relative to IS group ( $n=10$ mice per group). $\mathbf{G}$, Mice were killed $12 \mathrm{~h}$ after IS or 2, 6, 12, or $24 \mathrm{~h}$ after contextual $F C$ ( $n=$ 6 mice per group). $\boldsymbol{H}$, Representative images of Arc immunostaining in hippocampal CA1, CA3, and DG. Scale bar, $50 \mu \mathrm{m}$. I, Left, Proportion of Arc ${ }^{+}$CA1 neurons was upregulated 2 and $12 \mathrm{~h}$ after FC. Middle, Proportion of Arc ${ }^{+}$CA3 neurons was upregulated $2 \mathrm{~h}$ after FC. Right, Proportion of Arc ${ }^{+} \mathrm{DG}$ neurons was upregulated 2 and $6 \mathrm{~h}$ after FC. Error bars indicate mean \pm SEM. ${ }^{* *} p<0.01$. ${ }^{*} p<0.05$.

Mice received intraperitoneal injection of kainic acid $(20 \mathrm{mg} / \mathrm{kg}$, Tocris Bioscience) for the induction of seizures. Kainic acid was dissolved in saline.

Dendritic spine analysis. Mice were anesthetized with diethyl ether and transcardially perfused with PBS followed by $4 \%$ PFA. Brains were postfixed in $4 \%$ PFA overnight and coronally sectioned at a thickness of 100 $\mu \mathrm{m}$ with a microslicer (ZERO 1; Dosaka).

Images of basal and apical dendrites of $\mathrm{mGFP}^{+} \mathrm{CA} 1$ pyramidal neurons in the dorsal hippocampal CA1 region (bregma -1.3 to $-1.9 \mathrm{~mm}$ ) were obtained with a Leica SP8 confocal microscope at $63 \times$ under oilimmersion (NA, 1.4). To avoid interference from dendrites of other $\mathrm{mGFP}^{+}$neurons, only dendritic segments that were spatially isolated from the nearest dendrites were analyzed.

Spine detection and measurements were performed semiautomatically by the NeuronStudio software (Rodriguez et al., 2006, 2008). The NeuronStudio data are accurate, reproducible, robust, and noiseresistant enough to analyze morphological reorganization of CA1 dendritic spines (Kitanishi et al., 2009a). Once the starting points of dendritic tracing are manually determined, dendritic shafts are automatically detected. Then, the individual spines were automatically detected. Erroneous detection, such as short dendritic branches, optical noise, and very closely neighboring spines that were not automatically separable with NeuronStudio, were manually corrected by an experimenter blind to behavioral conditions. Then, the diameter of spine head and neck and the length of spines and dendritic shafts were measured with NeuronStudio. The number of spines per micrometer along the dendritic longitudinal axis was defined as the spine density. The spine shape was classified into mushroom, thin, and stubby spines (Harris et al., 1992). In brief, a spine with a head diameter $>0.4 \mu \mathrm{m}$ and ratio of the head diameter to the neck diameter $\geq 1.0$ was defined as a mushroom spine. Spines longer than $1.0 \mu \mathrm{m}$ were defined as thin spines, and the rest were classified as stubby spines. We compared dendritic spine density on basal dendrites within $100 \mu \mathrm{m}$ of the soma and on the apical dendrites within $200 \mu \mathrm{m}$ of the soma.

Data analysis. All values are mean \pm SEM. Statistical analysis was performed using one-way ANOVA, repeated-measures ANOVA, Tukey's test, Student's $t$ test, and paired $t$ test, where appropriate. $p<0.05$ is considered statistically significant. 
A

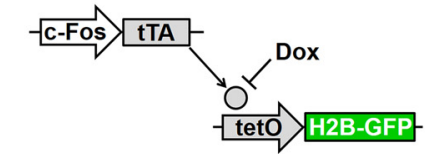

B

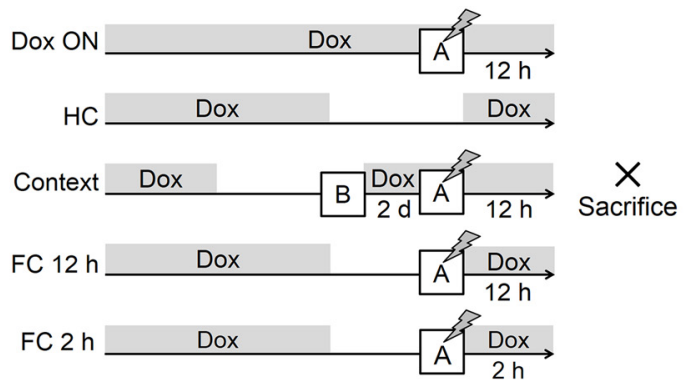

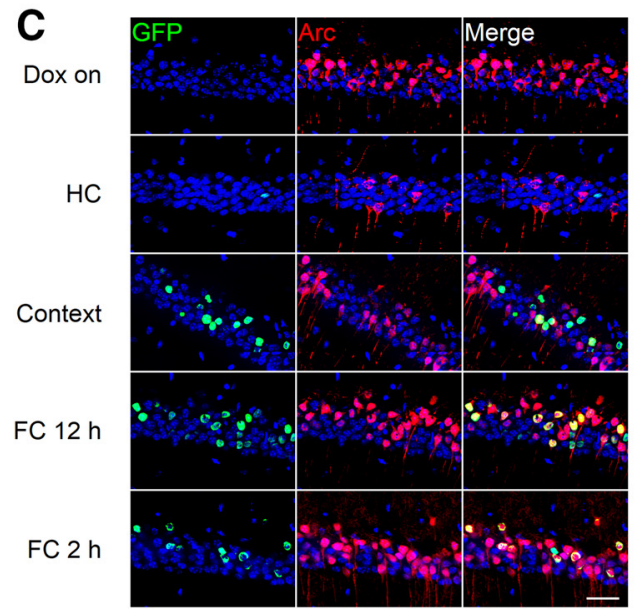
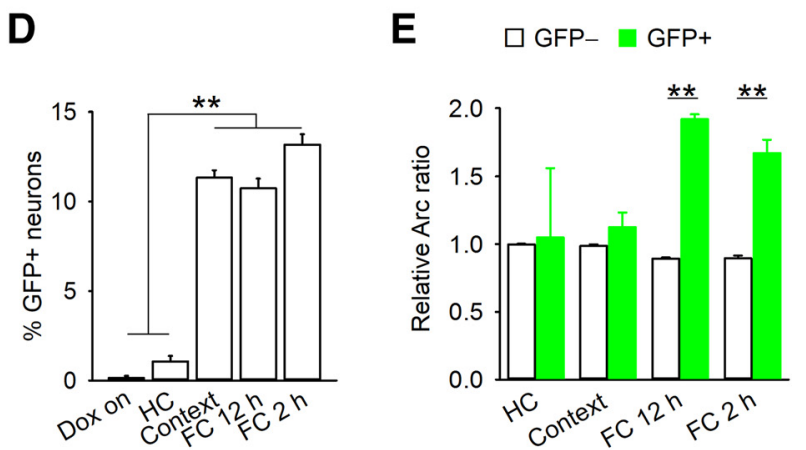

Figure 2. Hippocampal CA1 neurons activated during $\mathrm{FC}$ preferentially express Arc $12 \mathrm{~h}$ after conditioning. $A$, Activation of the $C$-Fos promoter leads to the expression of H2B-GFP fusion protein in the absence of Dox. B, Mice were subjected to contextual FC with Dox (Dox ON group) or without Dox (FC $12 \mathrm{~h}$ group) and killed $12 \mathrm{~h}$ later. The $\mathrm{FC} 2 \mathrm{~h}$ group was subjected to contextual $\mathrm{FC}$ without Dox and killed $2 \mathrm{~h}$ later. Mice in the context group were exposed to a neutral context without Dox, subjected to FC with Dox and killed $12 \mathrm{~h}$ later. The HC group was not subjected to FC. $C$, Representative images of Arc and H2B-GFP immunostaining in hippocampal CA1. Scale bar, $50 \mu \mathrm{m}$. D. Context ( $n=6$ mice, $781.7 \pm 43.4$ cells), FC $12 \mathrm{~h}(n=7 \mathrm{mice}, 731.3 \pm 61.3$ cells), and FC $2 \mathrm{~h}$ ( $n=6$ mice, $726.2 \pm 37.3$ cells) groups showed greater H2B-GFP expression than Dox ON ( $n=4$ mice, $977 \pm 304.3$ cells) and HC ( $n=6$ mice, $752.8 \pm 32.0$ cells) groups. $E$, Normalized ratio of $\mathrm{CA} 1$ neurons with Arc signals in $\mathrm{H}_{2} \mathrm{~B}_{-} \mathrm{GFP}^{-}$and $\mathrm{H} 2 \mathrm{~B}-\mathrm{GFP}{ }^{+}$neurons by proportion of overall $\mathrm{Arc}^{+}$neurons. $\mathrm{H} 2 \mathrm{~B}-\mathrm{GFP}^{+}$neurons are more likely to express Arc relative to $\mathrm{H} 2 \mathrm{~B}-\mathrm{GFP}{ }^{-}$neurons in $\mathrm{FC} 12$ and $2 \mathrm{~h}$ groups but not in control groups. Error bars indicate mean \pm SEM. ${ }^{* *} p<0.01$.

\section{Results}

Early and late Arc expression after contextual FC

To characterize Arc expression after learning, we measured hippocampal Arc levels after contextual FC. Mice were killed 2, 6, 12, or $24 \mathrm{~h}$ after contextual FC, and their hippocampal lysates were subjected to Western blotting with an anti-Arc antibody (Fig. $1 A)$. Following FC, hippocampal Arc levels increased at $2 \mathrm{~h}$, returned to basal levels at $6 \mathrm{~h}$, increased again at $12 \mathrm{~h}$, and returned to basal levels at $24 \mathrm{~h}$ (Fig. $1 B$ ) (one-way ANOVA, $F_{(5,42)}=7.5$, $p=4.4 \times 10^{-5}$; Tukey's post hoc test, naive vs $2 \mathrm{~h}, p=0.0037$; $12 \mathrm{~h}, p=0.0046)$. To test whether late Arc expression (Arc expression at $12 \mathrm{~h}$ ) depends on associative learning, Arc expression was measured $12 \mathrm{~h}$ after an IS session instead of a FC session (Fig. $1 E$ ). The IS protocol, which consisted of delivering footshocks to mice immediately after placing them in a chamber, temporally dissociated context and shock exposure in mice and induced poor memory retention (Fig. $1 C, D$ ) (Student's $t$ test, $t_{(10)}=13.4$, $\left.p=1.0 \times 10^{-7}\right)$. Arc levels $12 \mathrm{~h}$ after IS were comparable with basal levels (Fig. $1 F$ ) (one-way ANOVA, $F_{(2,27)}=5.4, p=0.011$; Tukey's post hoc test, FC vs IS, $p=0.028$ ). These data indicate that contextual FC induces late Arc expression in the hippocampus.

Next, we compared Arc expression after contextual FC among the CA1, CA3, and DG. Mice in the FC group were killed 2, 6, 12, or $24 \mathrm{~h}$ after contextual FC, and mice in the IS group were killed $12 \mathrm{~h}$ after an IS session (Fig. 1G). Brain slices were subjected to Arc immunohistochemistry, and CA1, CA3, and DG neurons expressing Arc were separately measured (Fig. $1 \mathrm{H}$ ). The propor- tion of CA1 neurons with Arc signals was increased 2 and $12 \mathrm{~h}$ after FC (Fig. 1I) (one-way ANOVA, $F_{(5,23)}=11.5, p=1.1 \times$ $10^{-5}$; Tukey's post hoc test, naive vs $2 \mathrm{~h}, p=2.6 \times 10^{-4} ; 12 \mathrm{~h}, p=$ 0.0019). In contrast, the proportion of CA3 neurons with Arc signals was increased only $2 \mathrm{~h}$ after FC (Fig. 1I) (one-way ANOVA, $F_{(5,23)}=3.7, p=0.014$; Tukey's post hoc test, naive vs $2 \mathrm{~h}, p=0.034 ; 12 \mathrm{~h}, p=1.00$ ). The proportion of DG neurons with Arc signals was increased 2 and $6 \mathrm{~h}$, but not $12 \mathrm{~h}$ after FC (Fig. 1I) (one-way ANOVA, $F_{(5,23)}=10.4, p=2.6 \times 10^{-5}$; Tukey's post hoc test, naive vs $2 \mathrm{~h}, p=4.0 \times 10^{-4} ; 6 \mathrm{~h}, p=0.017$; $12 \mathrm{~h}, p=1.0$ ). These data indicate that contextual FC induces late Arc expression in the hippocampal CA1 neurons.

Hippocampal CA1 neurons activated during FC preferentially express Arc $12 \mathrm{~h}$ after conditioning

Specific neuronal populations activated during learning are likely to contribute to the memory trace (Reijmers et al., 2007; Han et al., 2009; Liu et al., 2012; Nonaka et al., 2014). Because late Arc expression is related to associative learning, it is possible that neuronal populations activated during learning preferentially express Arc in the late phase. To test this possibility, we used FosH2BGFP mice. In these transgenic mice, tTA is induced by activation of the activity-dependent $c$-Fos promoter (Reijmers et al., 2007). In the absence of Dox, tTA binds to tet $O$ and then leads to expression of human histone $\mathrm{H} 2 \mathrm{~B}-\mathrm{GFP}$ fusion protein in active neurons (Fig. 2A) (Tayler et al., 2011, 2013). To examine whether neurons activated during learning express Arc, we first 
A

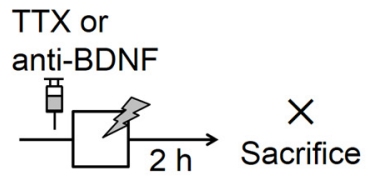

B
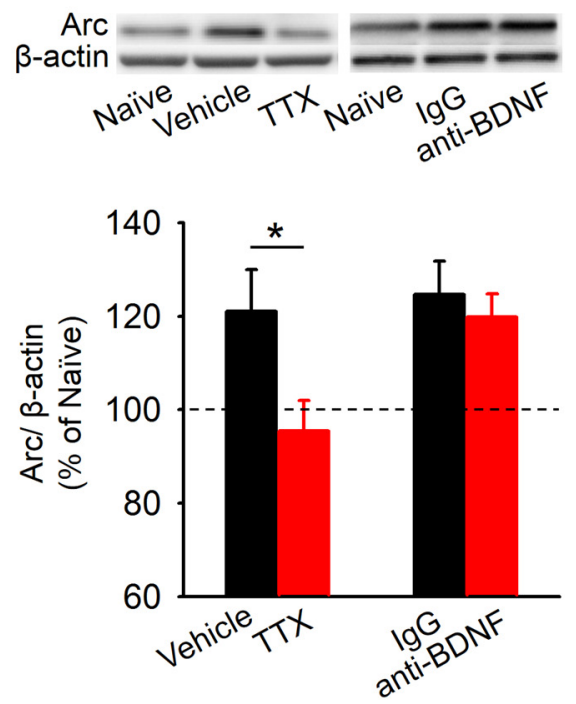

$\mathbf{E}$

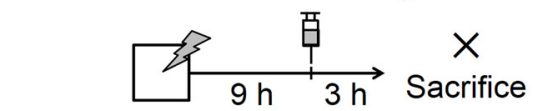

$\mathbf{F}$

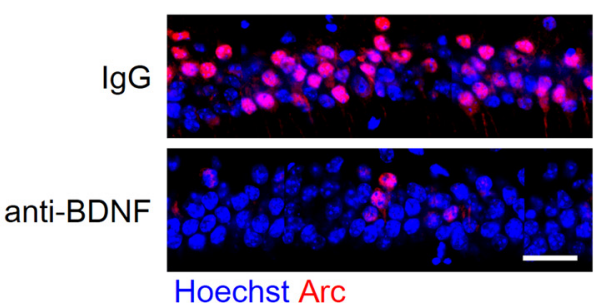

C

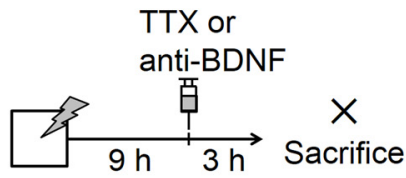

D

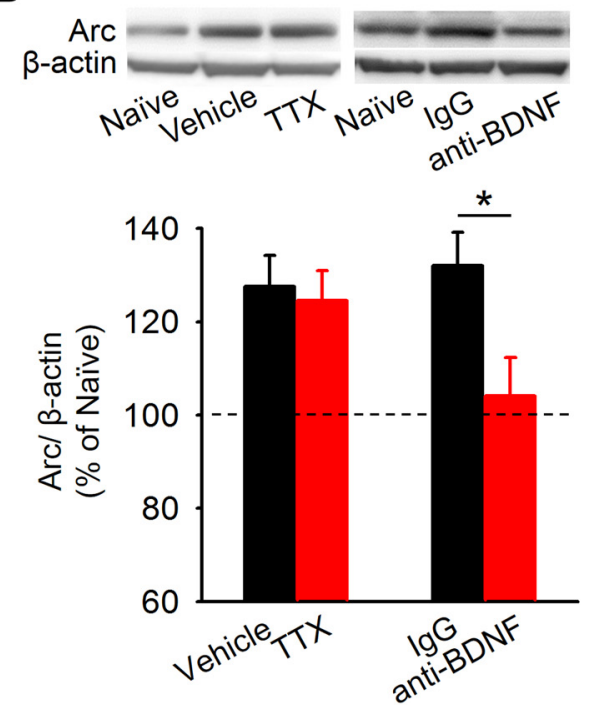

G

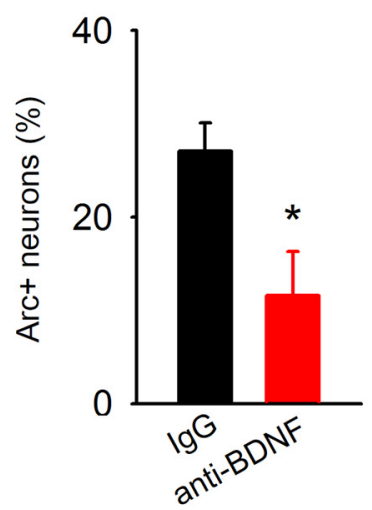

Figure 3. Early Arc expression depends on neuronal activity, and late Arc expression depends on BDNF. $\boldsymbol{A}$, Mice were infused with TTX, BDNF-blocking antibody (anti-BDNF), or vehicle into the dorsal hippocampus 30 min before FC and were killed $2 \mathrm{~h}$ later ( $n=8$ mice per group). $\boldsymbol{B}$, TTX, but not anti-BDNF, infusions inhibited early Arc expression. $\boldsymbol{C}$, Mice were infused with TTX, anti-BDNF, or vehicle into the dorsal hippocampus $9 \mathrm{~h}$ after $\mathrm{FC}$ and were killed $3 \mathrm{~h}$ later for Western blotting ( $n=8$ mice per group). D, Anti-BDNF, but not TTX, infusions inhibited late Arc expression. $\boldsymbol{E}$, Mice were infused with anti-BDNF or vehicle into the dorsal hippocampus $9 \mathrm{~h}$ after $\mathrm{FC}$ and were killed $3 \mathrm{~h}$ later for Arc immunostaining ( $n=8$ mice per group). $\boldsymbol{F}$, Representative images of Arc immunostaining in hippocampal CA1. Scale bar, $50 \mu \mathrm{m}$. G, Infusions of anti-BDNF decreased proportion of Arc ${ }^{+}$neurons in the CA1. Error bars indicate mean \pm SEM. ${ }^{*} p<0.05$.

labeled neurons activated during conditioning with H2B-GFP. Mice received contextual FC in the absence of Dox and were killed $12 \mathrm{~h}$ later (Fig. 2B; FC $12 \mathrm{~h}$ group). To rapidly inhibit H2B-GFP expression after conditioning, we gave a high dose of Dox $(1 \mathrm{~g} / \mathrm{kg})$ to mice. Arc and H2B-GFP immunostaining images were then obtained from the hippocampal CA1 region (Fig. 2C). H2B-GFP expression reflected neuronal activity during FC because FC with Dox resulted in little H2B-GFP expression (Dox $\mathrm{ON}$ group) and because fewer $\mathrm{H} 2 \mathrm{~B}-\mathrm{GFP}^{+}$neurons were observed in control mice in home cages (Fig. 2D) (one-way ANOVA, $F_{(4,24)}=201.2, p=2.0 \times 10^{-15}$; Tukey's post hoc test, Dox ON vs FC $12 \mathrm{~h}, p=4.3 \times 10^{-11}$; HC vs FC $12 \mathrm{~h}, p=2.6 \times$ $\left.10^{-11}\right)$. Late Arc expression was compared between H2B-GFP ${ }^{+}$ and $\mathrm{H} 2 \mathrm{~B}-\mathrm{GFP}^{-}$neurons. In the $\mathrm{FC} 12$ h group, $\mathrm{H} 2 \mathrm{~B}-\mathrm{GFP}^{+}$neu- rons were more likely to express Arc than $\mathrm{H} 2 \mathrm{~B}-\mathrm{GFP}^{-}$neurons (Fig. 2E) (repeated-measures ANOVA, $F_{(3,21)}=5.1, p=0.0080$; post hoc paired $t$ test, $p=3.1 \times 10^{-7}$ ). This preferential Arc expression was not observed in the home cage controls. These results suggest that, in the late phase after learning, the neurons activated during learning preferentially express Arc. In addition, H2B-GFP ${ }^{+}$ neurons preferentially express Arc $2 \mathrm{~h}$, as well as $12 \mathrm{~h}$, after FC in the mice that were subjected to FC without Dox (FC 2 h group; Fig. $2 B, E$ ) (post hoc paired $t$ test, $\mathrm{GFP}^{-} \mathrm{vs} \mathrm{GFP}^{+}$, FC $2 \mathrm{~h}, p=0.0012$ ).

To further test whether the neurons activated specifically during learning express Arc in the late phase after learning, we prepared another control (Fig. $2 A$, context group). These mice were exposed to a neutral context different from a conditioning context in the absence of Dox, received contextual FC with Dox $2 \mathrm{~d}$ 
A

Arc antisense ODN
or scrambled ODN

$\frac{\text { 臭 Kainic acid (i.p.) }}{3 \mathrm{~h}} \underset{\mathrm{S}}{\mathrm{f}} \underset{\text { Sacrifice }}{\times}$

B
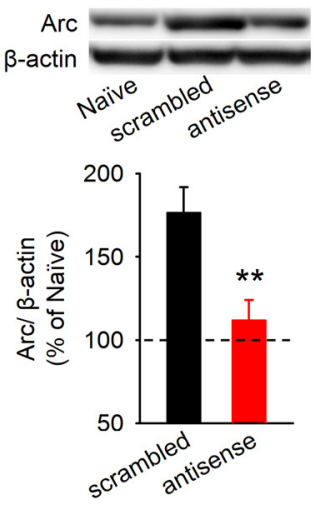

E

Arc antisense ODN or scrambled ODN
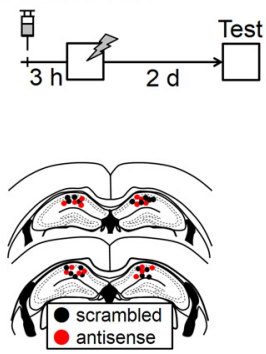

F

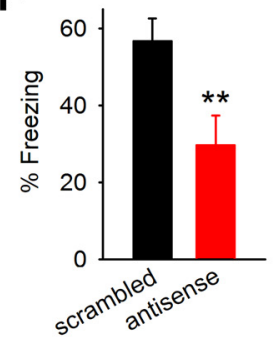

G

H
C

Arc antisense ODN

or scrambled ODN

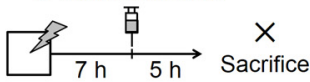

D
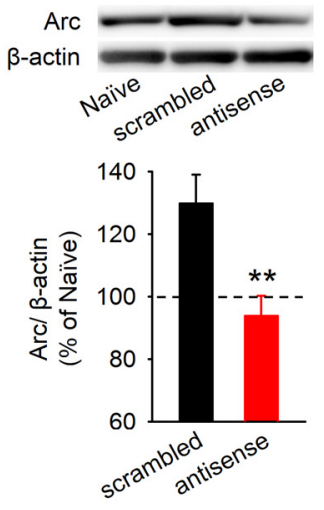

Arc antisense ODN

or scrambled ODN Test
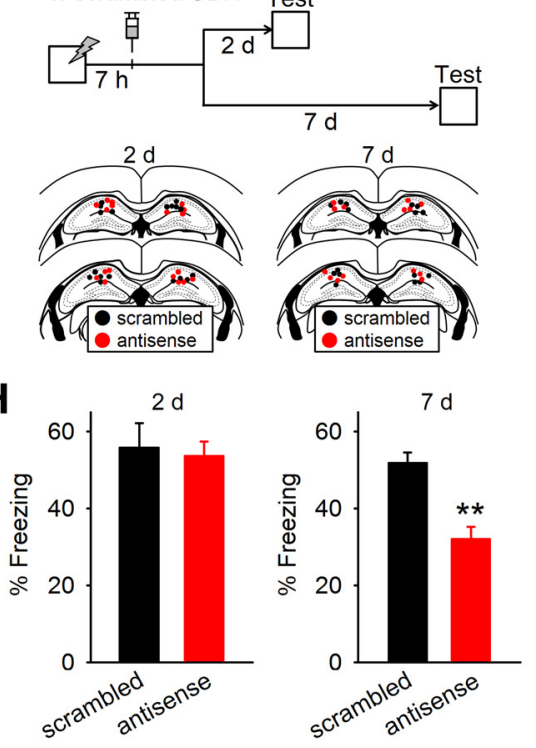

$J$

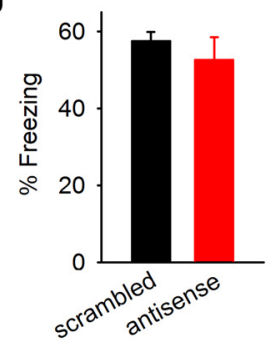

Figure 4. Early Arc expression contributes to memory formation, and late Arc expression contributes to memory persistence. $A, B$, Infusions of Arc antisense inhibited Arc expression in the CA1 induced by kainic acid injection ( $n=8$ mice per group). $\boldsymbol{C}, \boldsymbol{D}$, Infusions of Arc antisense 0DN7 hafter FC inhibited late Arcexpression in the CA1 ( $n=8$ mice per group). $\boldsymbol{E}$, $\boldsymbol{F}$, Mice infused with Arc antisense 0DN into the dorsal hippocampus $3 \mathrm{~h}$ before $\mathrm{FC}(n=8$ mice) showed less freezing behavior at $2 \mathrm{~d}$ afterFC, compared with the mice infused with scrambled ODN ( $n=9$ mice). $\mathbf{G}, \boldsymbol{H}$, Mice infused with Arc antisense 0DN into the dorsal hippocampus 7 h after FC ( $n=8$ or 9 mice) showed less freezing behavior at $7 \mathrm{~d}$ but not $2 \mathrm{~d}$ after FC, compared with the mice infused with scrambled 0 DN ( $n=8$ or 9 mice). $I, J$, Mice infused with Arc antisense and scrambled ODN into the dorsal hippocampus $19 \mathrm{~h}$ after FC ( $n=7$ mice) showed comparable freezing behavior at $7 \mathrm{~d}$ after FC. Error bars indicate mean \pm SEM. ${ }^{* *} p<0.01$.

later, and were killed $12 \mathrm{~h}$ later. In these mice, the H2B-GFP expression reflected the neural activity during exploration in the neutral context instead of in response to FC (Fig. 2D). In contrast to mice subjected to FC without Dox, late Arc signals were equally distributed in $\mathrm{H} 2 \mathrm{~B}-\mathrm{GFP}^{+}$and $\mathrm{H} 2 \mathrm{~B}-\mathrm{GFP}^{-}$neurons (Fig. 2E). Together, these results strongly indicate that hippocampal CA1 neurons activated during learning preferentially express Arc in the late phase after learning.

Early Arc expression depends on neuronal activity whereas late Arc expression depends on BDNF

Previous studies indicate that neuronal activity or BDNF application is sufficient to trigger Arc expression (Link et al., 1995; Lyford et al., 1995; Yin et al., 2002). However, the mechanisms for learning-induced early and late Arc expression are poorly understood. To explore whether early Arc expression depends on neuronal activity and/or BDNF, we infused TTX to block action potentials or function-blocking anti-BDNF antibody into the dorsal hippocampus 30 min before FC. The brains were removed $2 \mathrm{~h}$ after FC for Western blotting with an anti-Arc antibody (Fig. 3A). TTX infusions inhibited early Arc expression (one-way ANOVA, $F_{(2,21)}=3.7, p=0.042$; Tukey's post hoc test, vehicle vs TTX, $p=0.047)$, but anti-BDNF antibody infusions had no effect $\left(F_{(2,21)}=4.4, p=0.026\right.$; IgG vs anti-BDNF, $\left.p=0.85\right)$ (Fig. $\left.3 B\right)$. Consistent with a previous study reporting that blockade of BDNF function does not affect early Arc expression (Chen et al., 2012), our finding indicates that that early Arc expression depends on neuronal activity but not BDNF. 
A
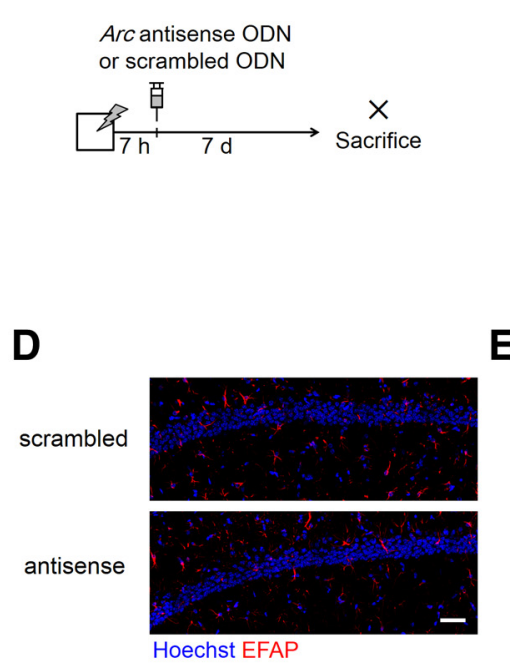

B

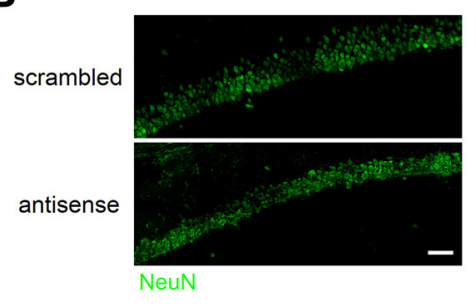

C

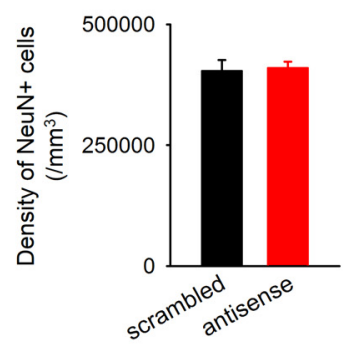

E

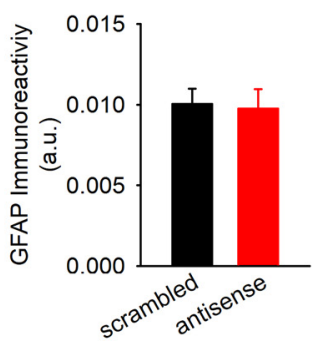

F

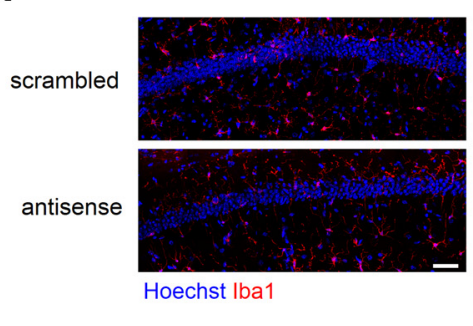

G

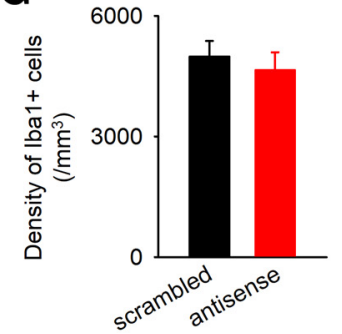

Figure 5. Infusions of Arc antisense ODN did not cause lesions or astrocyte and microglia response. $A$, Mice were infused with Arc antisense or scrambled ODN into the dorsal hippocampus $7 \mathrm{~h}$ after FC and killed $7 \mathrm{~d}$ later ( $n=4$ mice per group). $\boldsymbol{B}$, Representative images of NeuN immunostaining in hippocampal CA1. Scale bar, $50 \mu m$. $\boldsymbol{C}$, The density of NeuN ${ }^{+}$cells was comparable between mice with Arc antisense and scrambled ODN. D, Representative images of GFAP immunostaining in hippocampal CA1. Scale bar, $50 \mu$ m. $\boldsymbol{E}$, GFAP immunoreactivity was comparable between mice with Arc antisense and scrambled ODN. F, Representative images of Iba1 immunostaining in hippocampal CA1. Scale bar, $50 \mu \mathrm{m}$. G, The density of NeuN ${ }^{+}$cells was comparable between mice with Arc antisense and scrambled ODN. Error bars indicate mean \pm SEM.

To test whether late Arc expression depends on neuronal activity and/or BDNF, we infused TTX or function-blocking antiBDNF antibody into the dorsal hippocampus $9 \mathrm{~h}$ after FC. The brains were then removed $3 \mathrm{~h}$ later (Fig. $3 C$ ). In contrast to early Arc expression, anti-BDNF antibody infusions inhibited late Arc expression (one-way ANOVA, $F_{(2,21)}=5.0, p=0.016$; IgG vs anti-BDNF, $p=0.048)$, but TTX infusions did not affect late Arc expression $\left(F_{(2,21)}=6.5, p=0.0063\right.$; Tukey's post hoc test, vehicle vs TTX, $p=0.93$ ) (Fig. $3 D$ ). We also confirmed the effect of anti-BDNF antibody infusions on late Arc expression by Arc immunohistochemistry (Fig. 3E,F). Anti-BDNF infusions inhibited the increase in $\mathrm{Arc}^{+}$neurons in the CA1 $12 \mathrm{~h}$ after FC (Student's $t$ test, $t_{(8)}=2.8, p=0.024$ ) (Fig. $3 G$ ). Together, these results indicate that early Arc expression depends on neuronal activity, whereas late Arc expression depends on BDNF.

\section{Early Arc expression contributes to memory formation whereas late Arc expression contributes to memory persistence}

To parse the roles of early and late Arc expression in memory, we considered separate inhibition of early and late Arc expression with antisense ODNs. We previously confirmed that infusions of Arc antisense ODN (400 pmol/hemisphere) into the dorsal hippocampus inhibit hippocampal Arc expression $5 \mathrm{~h}$ after infusions and had no effect on the expression of other immediate early genes (Onoue et al., 2014). In this study, we first tested whether infusions of Arc antisense ODN inhibits Arc expression in the CA1. Mice received Arc antisense or scrambled ODN into the dorsal hippocampus $3 \mathrm{~h}$ before kainic acid seizure and were killed $2 \mathrm{~h}$ later (Fig. 4A), and their CA1 lysates were subjected to Western blotting. Infusions of $A r c$ antisense ODN inhibited CA1 Arc expression induced by kainic acid seizure (one-way ANOVA, $F_{(2,21)}=11.2, p=4.9 \times 10^{-4}$; Tukey's post hoc test, scrambled vs antisense, $p=0.0035$ ) (Fig. $4 B$ ).

To examine the role of early Arc expression in memory formation, we infused $A r c$ antisense or scrambled ODN into the dorsal hippocampus $3 \mathrm{~h}$ before FC, and $2 \mathrm{~d}$ later, we placed the mice in the conditioning context to test memory retention (Fig. 4E). Consistent with previous reports that early Arc expression is required for consolidation of spatial and fear memories (Guzowski et al., 2000; Ploski et al., 2008), inhibiting early Arc expression with Arc antisense ODN disrupted freezing behavior (Student's $t$ test, $t_{(15)}=3.4, p=0.0044$ ) (Fig. $4 F$ ), suggesting that early Arc expression contributes to memory formation.

To examine the role of late Arc expression, we first examined whether Arc antisense ODN inhibits late Arc expression in the CA1. Mice received Arc antisense or scrambled ODN into the dorsal hippocampus $7 \mathrm{~h}$ after FC and were killed $5 \mathrm{~h}$ later (Fig. $4 C)$. Their CA1 lysates were subjected to Western blotting. Infusions of $A r c$ antisense ODN inhibited late Arc expression in the hippocampal CA1 region (one-way ANOVA, $F_{(2,21)}=7.0, p=$ 0.0046; Tukey's post hoc test, scrambled vs antisense, $p=0.0057$ ) (Fig. 4D). Next, we prepared different mice and infused Arc antisense or scrambled ODN into the dorsal hippocampus $7 \mathrm{~h}$ after $\mathrm{FC}$, and $2 \mathrm{~d}$ later, we placed the mice in the conditioning context to test memory retention (Fig. 4G). In contrast to early Arc expression, inhibiting late Arc expression had no effect on freezing behavior at the $2 \mathrm{~d}$ test (Student's $t$ test, $t_{(16)}=0.29, p=0.77$ ) (Fig. $4 H$, left), suggesting that late Arc expression is not required for memory formation. To examine the effect of inhibiting late Arc expression on memory persistence, we prepared additional mice and tested memory retention $7 \mathrm{~d}$ instead of $2 \mathrm{~d}$ after infusions of Arc antisense of scrambled ODN (Fig. 4G). Inhibiting late Arc expression disrupted freezing behavior at the $7 \mathrm{~d}$ test $\left(t_{(14)}=\right.$ 4.8, $p=0.00028$ ) (Fig. 4H, right). The effect of Arc antisense ODN infusions depended on the interval between FC and the infusions because Arc antisense ODN infusions at $19 \mathrm{~h}$ after conditioning did not affect freezing behavior at the $7 \mathrm{~d}$ test (Student's $t$ test, $\left.t_{(12)}=0.75, p=0.47\right)($ Fig. $4 I, J)$.

Because degradation products of ODNs might be cytotoxic, it could be argued that effects of infusions of Arc antisense ODNs 
A

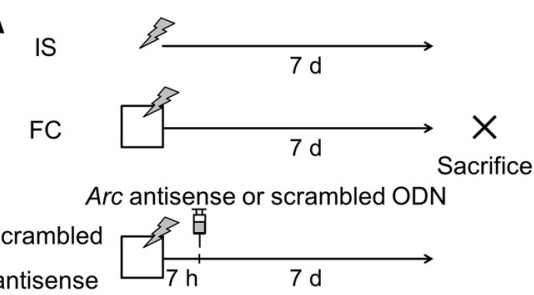

B

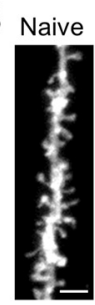

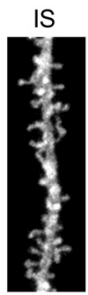

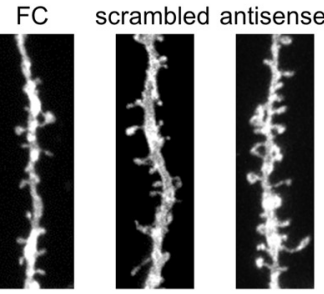

C Basal dendrites
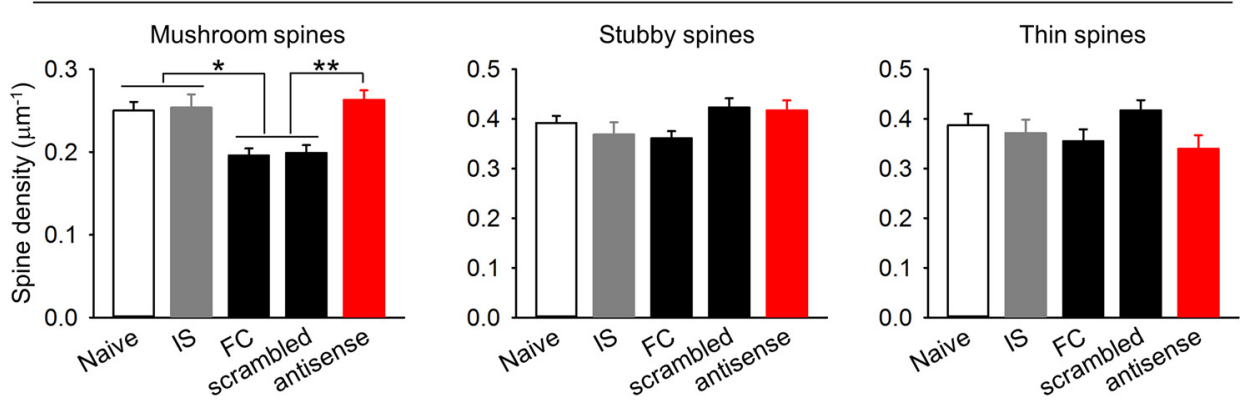

D

Basal dendrites
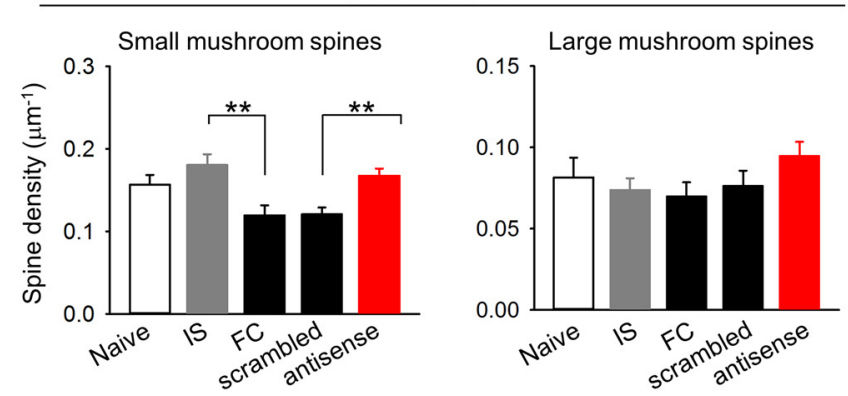

$\mathbf{E}$

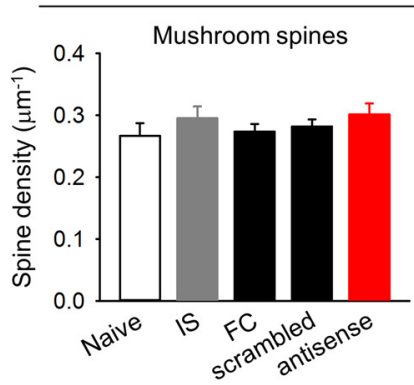

Apical dendrites
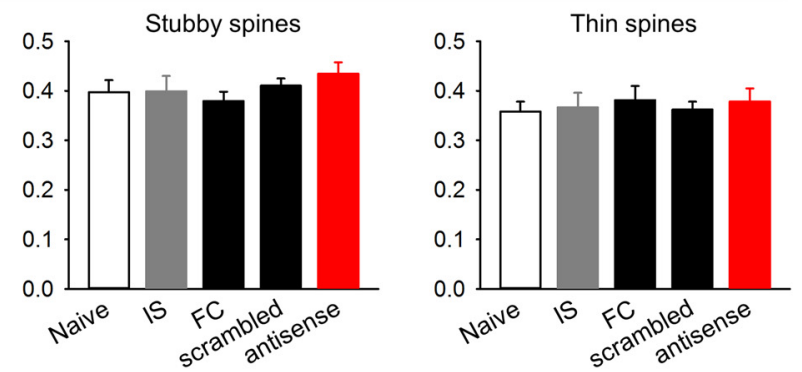

Figure 6. Late Arc expression prunes dendritic spines $7 \mathrm{~d}$ after FC. $\boldsymbol{A}$, Thy1-mGFP mice were used for visualizing the dendritic spines on CA1 pyramidal neurons. $\boldsymbol{B}$, Representative images of basal dendrites of $\mathrm{mGFP}^{+}$CA1 pyramidal neurons. Scale bar, $2 \mu \mathrm{m}$. C, FC reduced the density of mushroom spines in basal dendrites of CA1 pyramidal neurons, which was prevented by inhibiting late Arc expression [number of spines (Naive, IS, FC, scrambled, antisense): 1147, 838, 1372, 1152, 1111; number of neurons: 19, 12, 19, 19, 18; number of mice: 5, 5, 5, 4, 4]. D, FC preferentially eliminated small mushroom spines (head size $<0.6 \mu \mathrm{m}$ ) in basal dendrites in a late Arc-dependent manner. $\boldsymbol{E}$, Spine density in apical dendrites of CA1 pyramidal neurons was comparable among groups [number of spines (Naive, IS, FC, scrambled, antisense): 1281, 1382, 2236, 1065, 1220; number of neurons: 14, 16, 22, 17, 19; number of mice: 5, 5, 5, 4, 4]. Error bars indicate mean \pm SEM. ${ }^{*} p<0.05 ;{ }^{* *} p<0.01$.

are due to lesions or immune response but not inhibition of Arc. To test this possibility, we examined the neuronal density and astrocyte and microglia responses in the CA1 of the mice that received Arc antisense or scrambled ODN into the dorsal hippocampus $7 \mathrm{~h}$ after FC. They were killed $7 \mathrm{~d}$ later (Fig. $5 \mathrm{~A}$ ). The density of $\mathrm{NeuN}^{+}$cells (Student's $t$ test, $t_{(6)}=0.21, p=0.84$ ) (Fig. $5 B, C$ ), GFAP immunoreactivity (Student's $t$ test, $t_{(6)}=0.19$, $p=0.86$ ) (Fig. $5 D, E)$, and the density of $\mathrm{Iba}^{+}{ }^{+}$cells (Student's $t$ test, $\left.t_{(6)}=0.58, p=0.58\right)($ Fig. $5 F, G)$ were comparable between mice given $A r c$ antisense and scrambled ODN infusions.
Late Arc expression prunes dendritic spines $7 \mathbf{d}$ after FC

Spine elimination in the late phase after learning has been proposed as a mechanism for memory persistence (Liston et al., 2013). Although the role of Arc in spine remodeling associated with learning and memory has not been examined previously, Arc signaling can impact dendritic spine density and morphology (Peebles et al., 2010). Thus, we speculated that late Arc expression after FC is involved in spine remodeling associated with memory persistence.

To determine whether dendritic spine density changes following FC, we used Thy1-mGFP mice that express membrane- 
A

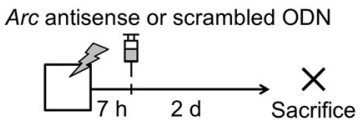

B

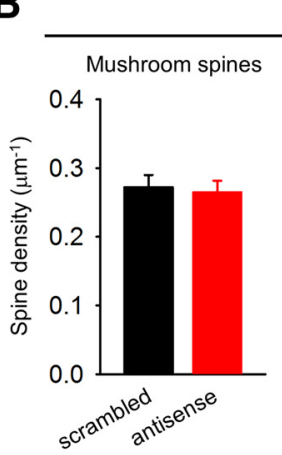

Basal dendrites

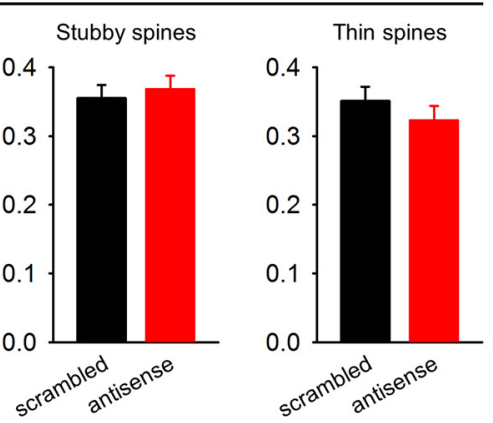

C

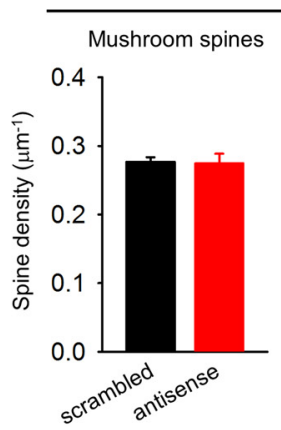

Apical dendrites

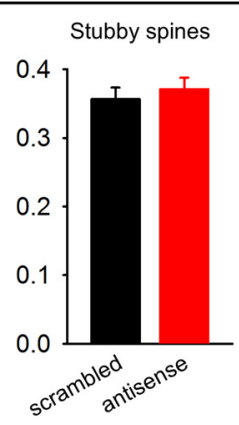

D

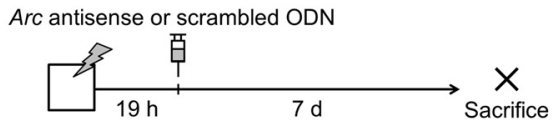

E

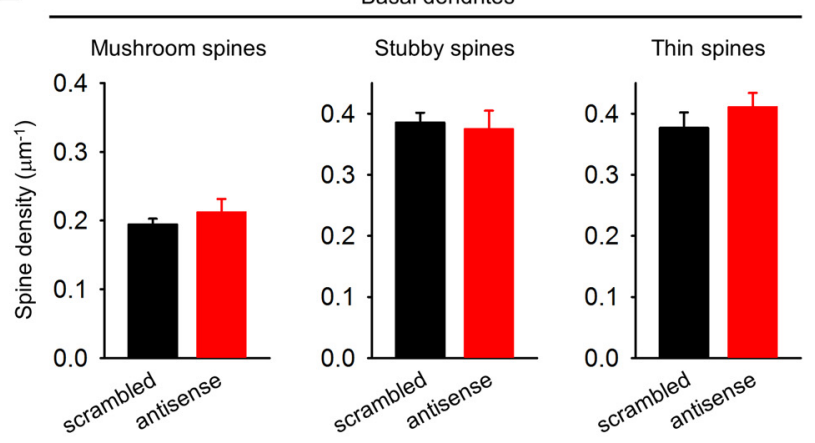

$\mathbf{F}$

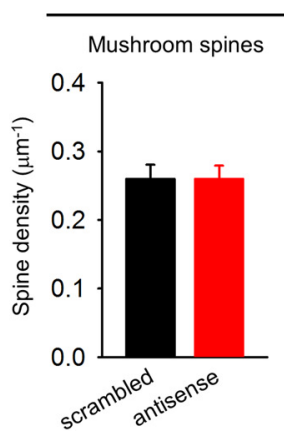

Apical dendrites

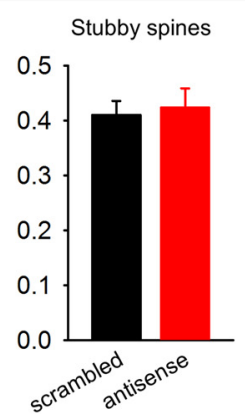

Thin spines

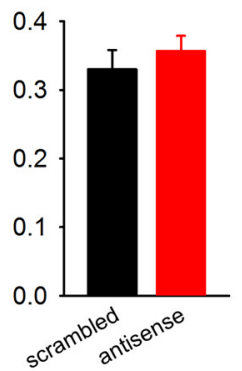

Figure 7. Effects of inhibiting Arc expression on spine reorganization requires $>2 \mathrm{~d}$ and depends on the time interval between conditioning and Arc inhibition. $\boldsymbol{A}$, Mice were subjected to contextual FC and infused with scrambled or Arc antisense 0DN into the dorsal hippocampus $7 \mathrm{~h}$ later. They were killed $2 \mathrm{~d}$ after FC. $\boldsymbol{B}$, Spine density in basal dendrites of CA1 pyramidal neurons was comparable among groups [number of spines (scrambled, antisense): 797, 843; number of neurons: 15, 16; number of mice: 3, 3]. $C$, Spine density in apical dendrites of CA1 pyramidal neurons was comparable among groups [number of spines (scrambled, antisense): 551, 745; number of neurons: 9, 12; number of mice: 3, 3]. D, Mice were subjected to contextual FC and infused with scrambled or Arc antisense ODN into the dorsal hippocampus $19 \mathrm{~h}$ later. They were killed $7 \mathrm{~d}$ after FC. $\boldsymbol{E}$, Spine density in basal dendrites of CA1 pyramidal neurons was comparable among groups. $\boldsymbol{F}$, Spine density in apical dendrites of (A1 pyramidal neurons was comparable among groups [number of spines (scrambled, antisense): 1205, 540; number of neurons: 9,$9 ;$ number of mice: 3, 3]. Error bars indicate mean \pm SEM.

targeted EGFP in CA1 neurons (Kitanishi et al., 2009a, b). The spine density of hippocampal CA1 neurons was measured $7 \mathrm{~d}$ after contextual FC (FC group) (Fig. 6A, B). Compared with naive control mice, the density of mushroom spines on CA1 basal dendrites was reduced $7 \mathrm{~d}$ after FC (one-way ANOVA, $F_{(4,79)}=$ 8.6, $p=8.7 \times 10^{-6}$; naive vs FC, $p=0.018$ ) (Fig. 6C). To test whether this spine reduction is related to associative fear memory, we measured spine density $7 \mathrm{~d}$ after IS group. In contrast to FC, IS did not affect the density of mushroom spines (FC vs IS, $p=0.0040$ ) (Fig. 6C). These results suggest that spine loss is related to associative fear memory.

To test whether late Arc expression is involved in the spine elimination, we measured spine density of CA1 neurons from mice with inhibited late Arc expression. Mice were given intrahippocampal infusions of Arc antisense or scrambled ODN $7 \mathrm{~h}$ after contextual FC and killed $7 \mathrm{~d}$ after conditioning for spine analysis (Fig. 6A). Although the density of mushroom spines was reduced in the mice given scrambled ODN infusions, this loss was prevented by hippocampal infusions of Arc antisense ODN (naive vs scrambled, $p=0.030$; scrambled vs antisense, $p=6.7 \times$ $10^{-4}$ ) (Fig. 6C). Separate analysis of small (head diameter $<0.6$ $\mu \mathrm{m}$ ) and large (head diameter $\geq 0.6 \mu \mathrm{m}$ ) mushroom spines revealed that FC preferentially eliminated small mushroom spines in a late Arc-dependent manner (repeated-measures ANOVA, group $\times$ type, small vs large spines, $F_{(8,160)}=3.0, p=0.0037$; IS vs FC, small spines, $p=0.0013$; scrambled vs antisense, small spines, $p=0.018$ ) (Fig. $6 D$ ). In contrast, the density of thin and stubby spines on basal dendrites (thin spines, $F_{(4,79)}=1.6, p=$ 0.19 ; stubby spines, $F_{(4,79)}=2.4, p=0.057$ ) and all types of spines on apical dendrites were comparable among groups (mushroom spines, $F_{(4,83)}=0.79, p=0.53$; thin spines, $F_{(4,83)}=0.16, p=$ 0.96 ; stubby spines, $F_{(4,83)}=0.93, p=0.45$ ) (Fig. $6 C, E$ ). These results indicate that, dependent on late Arc expression, FC prunes small mushroom spines on CA1 basal dendrites.

We next asked whether inhibiting late Arc expression affects the spine density $2 \mathrm{~d}$ after FC. Mice were given intrahippocampal infusions of $A r c$ antisense or scrambled ODN $7 \mathrm{~h}$ after contextual FC and killed $2 \mathrm{~d}$ after conditioning (Fig. $7 A$ ). In contrast to $7 \mathrm{~d}$ after conditioning, inhibiting late Arc expression had no effect on the density of all types of spines both on basal and apical dendrites $2 \mathrm{~d}$ after conditioning (all comparison, $p>0.3$ ) (Fig. $7 \mathrm{~B}, \mathrm{C}$ ). This result indicates that late Arc expression requires at least $2 \mathrm{~d}$ to modify spine density and freezing behavior.

To explore whether the effect of inhibiting Arc translation on spine reorganization depends on the time interval between conditioning and Arc inhibition, we infused Arc antisense or scram- 
A

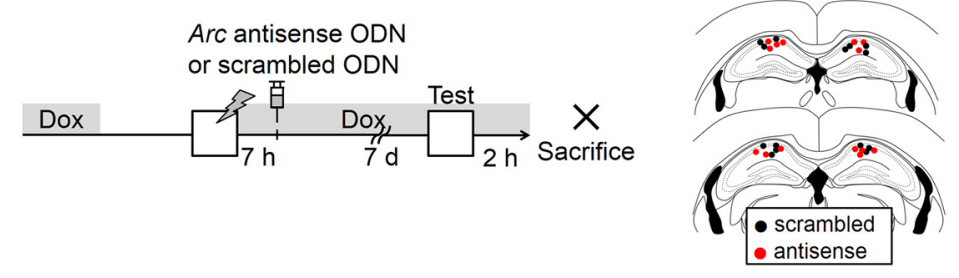

C
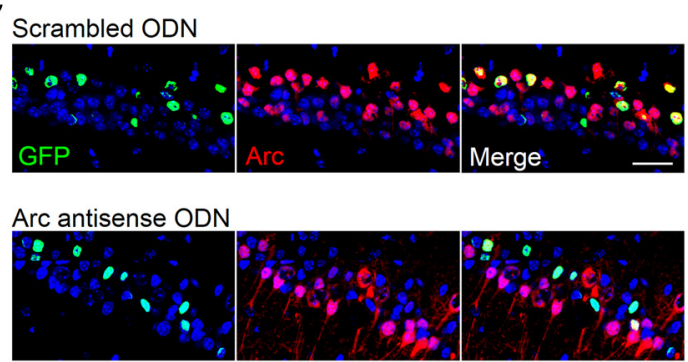

D

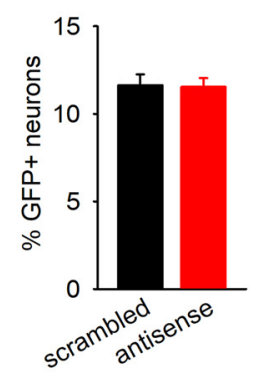

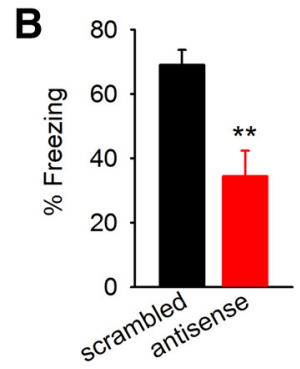

E

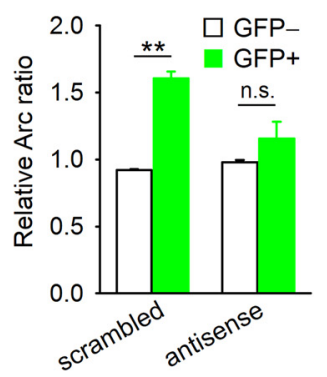

Figure 8. Late Arc expression is required for reactivation of neurons that were activated during learning. $A$, Fos- $\mathrm{H} 2 \mathrm{BGFP}$ mice were subjected to $\mathrm{FC}$ in the absence of Dox and received infusions of Arc antisense or scrambled ODN into the dorsal hippocampus $7 \mathrm{~h}$ later. Memory retention was tested $7 \mathrm{~d}$ after FC and killed $2 \mathrm{~h}$ later. $\boldsymbol{B}$, Mice with Arc antisense 0DN infusions ( $n=7$ mice) showed less freezing behavior than mice with scrambled ODN infusions ( $n=7$ mice). $C$, Representative images of Arc and H2B-GFP immunostaining in hippocampal CA1 (scrambled, $660.0 \pm 12.4$ cells; antisense, $679.9 \pm 17.0$ cells). Scale bar, $50 \mu \mathrm{m}$. D, No difference in proportion of CA1 neurons with H2B-GFP signals. $\boldsymbol{E}$, Normalized ratio of CA1 neurons with Arc signals in H2B-GFP - and $\mathrm{H} 2 \mathrm{~B}-\mathrm{GFP}^{+}$neurons by proportion of overall Arc ${ }^{+}$neurons. $\mathrm{H} 2 \mathrm{~B}-\mathrm{GFP}{ }^{+}$neurons preferentially express Arc in mice given scrambled ODN but not Arc antisense ODN infusions. Error bars indicate mean \pm SEM. ${ }^{* *} p<0.01$. n.S., Not significant.

bled ODN into the dorsal hippocampus $19 \mathrm{~h}$ instead of $7 \mathrm{~h}$ after FC and removed the brains for spine analysis $7 \mathrm{~d}$ after conditioning (Fig. 7D). The density of all types of spines both on basal and apical dendrites was comparable between groups (all comparison, $p>0.3$ ) (Fig. $7 E, F)$. This result indicates that the effect of inhibiting Arc expression on spine reorganization is time-limited.

\section{Late Arc expression is required for reactivation of neuronal ensembles activated during FC}

Selective reactivation of neurons activated during learning is essential for memory recall (Reijmers et al., 2007; Han et al., 2009; Liu et al., 2012). Spine elimination potentially enhances signalto-noise ratios to encode information during learning and then contributes to reactivation of neuronal ensembles that were established during learning (Grønli et al., 2013; Schacher and $\mathrm{Hu}$, 2014). Thus, we speculated that late Arc expression is involved in reactivation of neuronal ensembles, possibly through spine elimination. To test this possibility, we examined reactivation of neuronal ensembles that were activated during learning in mice with inhibited late Arc expression. We subjected Fos-H2BGFP mice to FC in the absence of Dox (Fig. $8 A$ ). Then, we fed these mice with $1 \mathrm{~g} / \mathrm{kg}$ Dox to rapidly inhibit H2B-GFP expression after conditioning. They received hippocampal infusions of $A r c$ antisense or scrambled ODN $7 \mathrm{~h}$ later. They were exposed to the conditioning context as a memory retrieval session $7 \mathrm{~d}$ later and killed $2 \mathrm{~h}$ afterward. Consistent with the previous result (Fig. 4D), inhibiting late Arc expression disrupted freezing behavior at $7 \mathrm{~d}$ (Student's $t$ test, $t_{(12)}=3.8, p=0.0027$ ) (Fig. $8 B$ ). This behavioral protocol allowed us to identify $\mathrm{H} 2 \mathrm{~B}-\mathrm{GFP}^{+}$neurons as the neurons activated during $\mathrm{FC}$ and $\mathrm{Arc}^{+}$neurons as the neurons activated during the retrieval session. Arc and GFP immunostainings were obtained from the hippocampal CA1 region (Fig. $8 C$ ). The proportion of $\mathrm{H} 2 \mathrm{~B}-\mathrm{GFP}^{+}$neurons was comparable between mice given $A r c$ antisense and scrambled ODN infusions (Fig. $8 D)$. In the mice given scrambled ODN infusions, H2B-GFP ${ }^{+}$ neurons were more likely to be positive for Arc relative to $\mathrm{H} 2 \mathrm{~B}$ $\mathrm{GFP}^{-}$neurons (repeated-measures ANOVA, $F_{(1,12)}=10.8, p=$ 0.0065 ; post hoc paired $t$ test, $\mathrm{GFP}^{+} \mathrm{vs} \mathrm{GFP}^{-}$in scrambled group, $\left.p=2.2 \times 10^{-5}\right)($ Fig. $8 E$ ), suggesting that the neurons activated during learning were preferentially activated during memory retrieval. This result is consistent with a previous study reporting that hippocampal CA1 neurons activated during contextual FC are reactivated during retrieval of a memory (Tayler et al., 2013). In the mice given Arc antisense ODN infusions, however, the preferential Arc expression in $\mathrm{H} 2 \mathrm{~B}-\mathrm{GFP}^{+}$neurons was abolished $\left(\mathrm{GFP}^{+}\right.$vs $\mathrm{GFP}^{-}$in antisense group, $\left.p=0.25\right)$ (Fig. $\left.8 E\right)$. The total proportion of $\mathrm{Arc}^{+}$neurons was comparable between mice administered scrambled and Arc antisense ODN infusions (scrambled ODN, $35.6 \pm 1.0 \%$; Arc antisense ODN, $34.9 \pm 0.85 \%$; Student's $t$ test, $\left.t_{(12)}=0.50, p=0.63\right)$. These results indicate that late Arc expression is required for the reactivation of neuronal ensembles that were activated during initial learning.

\section{Discussion}

In the present study, we characterized late Arc expression in the hippocampus following associative fear learning. We discovered that Arc is upregulated $12 \mathrm{~h}$ after contextual FC preferentially in CA1 neurons activated during conditioning in a BDNF-dependent manner. We also found that inhibiting late Arc expression impairs delayed elimination of dendritic spines, reactivation of neurons activated during conditioning, and expression of conditioned fear $7 \mathrm{~d}$ after initial FC. These findings suggest that BDNF-dependent late Arc expression eliminates dendritic spines and stabilizes neuronal ensembles to prolong long-term memories.

Intracellular molecular cascades are likely to be involved in late Arc expression. CA1 neurons activated during FC preferen- 
tially expressed late Arc compared with those not activated during conditioning. In addition, TTX infusions did not affect late Arc expression, suggesting that action potential-dependent neurotransmission, at least shortly before late Arc expression, is not essential for Arc expression. In contrast, function-blocking antiBDNF antibody inhibited late Arc expression. This result suggests that BDNF triggers late Arc expression. Indeed, previous studies have reported that BDNF is induced in the hippocampus and amygdala 8-12 h after contextual FC, inhibitory avoidance, and conditioned taste aversion tasks (Bekinschtein et al., 2007; Ou et al., 2010; Ma et al., 2011). This late-phase expression of BDNF is regulated via autoregulatory feedback loop cooperated with CCAAT-enhancer binding protein $\beta$ expression (BambahMukku et al., 2014). Moreover, applying BDNF to cultured neurons is sufficient to induce Arc expression (Yin et al., 2002). Together, molecular cascades that are initiated by learning presumably lead to late-phase expression of BDNF, and then BDNF is likely to trigger Arc expression in an autocrine manner (Kokaia et al., 1993; Zakharenko et al., 2003).

Memory recall requires stable reactivation of neuronal ensembles formed by learning (Han et al., 2007, 2009; Liu et al., 2012; Kim et al., 2014). Indeed, CA1 neurons activated during contextual FC are reactivated during memory retrieval (Tayler et al., 2013). This reactivation occurs at 2 and $14 \mathrm{~d}$ after conditioning, indicating that stable neuronal ensembles in CA1 established by learning persist for at least $14 \mathrm{~d}$. In this study, we have shown that inhibiting late Arc expression disrupted reactivation of neuronal ensembles, as well as freezing behavior, $7 \mathrm{~d}$ after FC. These findings indicate that late Arc expression is essential for stabilization of neuronal ensembles formed by learning.

At the cellular level, Arc regulates morphological remodeling of dendritic spines and is essential for shaping functional circuits. A previous study using $\mathrm{Arc}^{-1-}$ mice has shown that Arc loss leads to an increase in the proportion of mushroom spines on CA1 neurons with a decrease in the proportion of thin spines and increased epileptic-like network hyperexcitability (Peebles et al., 2010). Overall Arc expression may therefore regulate spine morphology and density, as well as stabilize network activity. In our current study, we focused on the role of learning-induced Arc in learning-related spine reorganization and network activity. We found that late Arc expression is required for spine elimination observed $7 \mathrm{~d}$ after FC and for persistence of neuronal ensembles that were established during learning. Because the strengthening of specific synaptic connections underlies a memory trace, elimination of redundant synapses could refine functional circuits for memory. Thus, late Arc-dependent spine pruning might be associated with persistence of neuronal ensembles established by learning. Interestingly, separate analyses of small and large mushroom spines revealed that small mushroom spines are selectively decreased $7 \mathrm{~d}$ after FC. Because learning in vivo and synaptic potentiation in vitro are tightly associated with spine enlargement (Matsuzaki et al., 2004; Roberts et al., 2010), it is possible that large mushroom spines, which are not eliminated $7 \mathrm{~d}$ after $\mathrm{FC}$, are involved in a fear memory trace.

De novo spine formation has been proposed as a structural basis for memory traces (Bailey and Kandel, 1993); in our study, however, we did not detect an increase in spine density $7 \mathrm{~d}$ after contextual FC. Similarly, no changes in spine density $1-3 \mathrm{~d}$ after contextual FC have been reported in another study using DiI for visualizing dendritic spines (Matsuo et al., 2008). Presumably, spine elimination may equal spine formation, preserving overall density. Moreover, in some conditions, spine formation may not make a central contribution to a memory trace (Lai et al., 2012;
Sanders et al., 2012). Indeed, a recent time-lapse imaging study of the frontal association cortex found that, after FC, spine elimination is preferentially observed relative to spine formation (Lai et al., 2012).

Spine reduction following FC is selective for mushroom spines on basal dendrites. Selective reduction of mushroom spines might reflect thinning of spine heads, converting originally small mushroom spines into thin spines and eliminating small thin spines altogether. Indeed, Arc overexpression in hippocampal neurons reduces spine thickness (Peebles et al., 2010). A possible explanation for preferential spine reduction on basal but not apical dendrites is that cholinergic modulation enhances synaptic plasticity on basal dendrites. More cholinergic input arrives in the striatum oriens where CA1 basal dendrites are located rather than in the striatum radiatum (Schäfer et al., 1998). Because acetylcholine lowers the threshold for synaptic changes of CA1 neurons (Ovsepian et al., 2004), dendritic spines on basal dendrites could be more susceptible than those on apical dendrites (Perez-Cruz et al., 2011). Indeed, selective spine remodeling on basal dendrites has been previously reported (Moser et al., 1997; Leuner et al., 2003; Santos et al., 2004).

In conclusion, we found that late Arc expression depends on BDNF, but not neuronal activity, and is critical for delayed elimination of dendritic spines and the stable reactivation of neuronal ensembles. Late Arc expression seems to slowly refine functional circuits to prolong long-term fear memories. The precise timing of gene expression is thus crucial to both structural and functional activity-dependent changes underlying learning and animal behavior.

\section{References}

Bailey CH, Kandel ER (1993) Structural changes accompanying memory storage. Annu Rev Physiol 55:397-426. CrossRef Medline

Bambah-Mukku D, Travaglia A, Chen DY, Pollonini G, AlberiniCM (2014) Apositive autoregulatory BDNF feedback loop via $\mathrm{C} / \mathrm{EBP} \beta$ mediates hippocampal memory consolidation. J Neurosci 34:12547-12559. CrossRef Medline

Bekinschtein P, Cammarota M, Igaz LM, Bevilaqua LR, Izquierdo I, Medina JH (2007) Persistence of long-term memory storage requires a late protein synthesis- and BDNF-dependent phase in the hippocampus. Neuron 53:261-277. CrossRef Medline

Chen DY, Bambah-Mukku D, Pollonini G, Alberini CM (2012) Glucocorticoid receptors recruit the CaMKII $\alpha$-BDNF-CREB pathways to mediate memory consolidation. Nat Neurosci 15:1707-1714. CrossRef Medline

De Paola V, Arber S, Caroni P (2003) AMPA receptors regulate dynamic equilibrium of presynaptic terminals in mature hippocampal networks. Nat Neurosci 6:491-500. CrossRef Medline

Gao M, Sossa K, Song L, Errington L, Cummings L, Hwang H, Kuhl D, Worley P, Lee HK (2010) A specific requirement of Arc/Arg3.1 for visual experience-induced homeostatic synaptic plasticity in mouse primary visual cortex. J Neurosci 30:7168-7178. CrossRef Medline

Grønli J, Soulé J, Bramham CR (2013) Sleep and protein synthesisdependent synaptic plasticity: impacts of sleep loss and stress. Front Behav Neurosci 7:224. CrossRef Medline

Guzowski JF, Lyford GL, Stevenson GD, Houston FP, McGaugh JL, Worley PF, Barnes CA (2000) Inhibition of activity-dependent arc protein expression in the rat hippocampus impairs the maintenance of long-term potentiation and the consolidation of long-term memory. J Neurosci 20:3993-4001. Medline

Han JH, Kushner SA, Yiu AP, Cole CJ, Matynia A, Brown RA, Neve RL, Guzowski JF, Silva AJ, Josselyn SA (2007) Neuronal competition and selection during memory formation. Science 316:457-460. CrossRef Medline

Han JH, Kushner SA, Yiu AP, Hsiang HL, Buch T, Waisman A, Bontempi B, Neve RL, Frankland PW, Josselyn SA (2009) Selective erasure of a fear memory. Science 323:1492-1496. CrossRef Medline

Harris KM, Jensen FE, Tsao B (1992) Three-dimensional structure of dendritic spines and synapses in rat hippocampus (CA1) at postnatal day 15 and adult ages: implications for the maturation of synaptic physiology and long-term potentiation. J Neurosci 12:2685-2705. Medline 
Hübener M, Bonhoeffer T (2010) Searching for engrams. Neuron 67:363371. CrossRef Medline

Johansen JP, Cain CK, Ostroff LE, LeDoux JE (2011) Molecular mechanisms of fear learning and memory. Cell 147:509-524. CrossRef Medline

Kim J, Kwon JT, Kim HS, Josselyn SA, Han JH (2014) Memory recall and modifications by activating neurons with elevated CREB. Nat Neurosci 17:65-72. CrossRef Medline

Kitanishi T, Ikegaya Y, Matsuki N (2009a) Behaviorally evoked transient reorganization of hippocampal spines. Eur J Neurosci 30:560-566. CrossRef Medline

Kitanishi T, Ikegaya Y, Matsuki N, Yamada MK (2009b) Experiencedependent, rapid structural changes in hippocampal pyramidal cell spines. Cereb Cortex 19:2572-2578. CrossRef Medline

Kokaia Z, Bengzon J, Metsis M, Kokaia M, Persson H, Lindvall O (1993) Coexpression of neurotrophins and their receptors in neurons of the central nervous system. Proc Natl Acad Sci U S A 90:6711-6715. CrossRef Medline

Lai CS, Franke TF, Gan WB (2012) Opposite effects of fear conditioning and extinction on dendritic spine remodelling. Nature 483:87-91. CrossRef Medline

Leuner B, Falduto J, Shors TJ (2003) Associative memory formation increases the observation of dendritic spines in the hippocampus. J Neurosci 23:659-665. Medline

Link W, Konietzko U, Kauselmann G, Krug M, Schwanke B, Frey U, Kuhl D (1995) Somatodendritic expression of an immediate early gene is regulated by synaptic activity. Proc Natl Acad Sci U S A 92:5734-5738. CrossRef Medline

Liston C, Cichon JM, Jeanneteau F, Jia Z, Chao MV, Gan WB (2013) Circadian glucocorticoid oscillations promote learning-dependent synapse formation and maintenance. Nat Neurosci 16:698-705. CrossRef Medline

Liu X, Ramirez S, Pang PT, Puryear CB, Govindarajan A, Deisseroth K, Tonegawa S (2012) Optogenetic stimulation of a hippocampal engram activates fear memory recall. Nature 484:381-385. CrossRef Medline

Lyford GL, Yamagata K, Kaufmann WE, Barnes CA, Sanders LK, Copeland NG, Gilbert DJ, Jenkins NA, Lanahan AA, Worley PF (1995) Arc, a growth factor and activity-regulated gene, encodes a novel cytoskeletonassociated protein that is enriched in neuronal dendrites. Neuron 14:433445. CrossRef Medline

Ma L, Wang DD, Zhang TY, Yu H, Wang Y, Huang SH, Lee FS, Chen ZY (2011) Region-specific involvement of BDNF secretion and synthesis in conditioned taste aversion memory formation. J Neurosci 31:2079-2090. CrossRef Medline

Matsuo N, Reijmers L, Mayford M (2008) Spine-type-specific recruitment of newly synthesized AMPA receptors with learning. Science 319:11041107. CrossRef Medline

Matsuzaki M, Honkura N, Ellis-Davies GC, Kasai H (2004) Structural basis of long-term potentiation in single dendritic spines. Nature 429:761-766. CrossRef Medline

McCurry CL, Shepherd JD, Tropea D, Wang KH, Bear MF, Sur M (2010) Loss of Arc renders the visual cortex impervious to the effects of sensory experience or deprivation. Nat Neurosci 13:450-457. CrossRef Medline

Mikuni T, Uesaka N, Okuno H, Hirai H, Deisseroth K, Bito H, Kano M (2013) Arc/Arg3.1 is a postsynaptic mediator of activity-dependent synapse elimination in the developing cerebellum. Neuron 78:1024-1035. CrossRef Medline

Moser MB, Trommald M, Egeland T, Andersen P (1997) Spatial training in a complex environment and isolation alter the spine distribution differently in rat CA1 pyramidal cells. J Comp Neurol 380:373-381. CrossRef Medline

Nomura H, Matsuki N (2008) Ethanol enhances reactivated fear memories. Neuropsychopharmacology 33:2912-2921. CrossRef Medline

Nomura H, Nonaka A, Imamura N, Hashikawa K, Matsuki N (2012) Memory coding in plastic neuronal subpopulations within the amygdala. Neuroimage 60:153-161. CrossRef Medline

Nonaka A, Toyoda T, Miura Y, Hitora-Imamura N, Naka M, Eguchi M, Yamaguchi S, Ikegaya Y, Matsuki N, Nomura H (2014) Synaptic plasticity associated with a memory engram in the basolateral amygdala. J Neurosci 34:9305-9309. CrossRef Medline

Onoue K, Nakayama D, Ikegaya Y, Matsuki N, Nomura H (2014) Fear extinction requires Arc/Arg3.1 expression in the basolateral amygdala. Mol Brain 7:30. CrossRef Medline

Ou LC, Yeh SH, Gean PW (2010) Late expression of brain-derived neurotrophic factor in the amygdala is required for persistence of fear memory. Neurobiol Learn Mem 93:372-382. CrossRef Medline
Ovsepian SV, Anwyl R, Rowan MJ (2004) Endogenous acetylcholine lowers the threshold for long-term potentiation induction in the CA1 area through muscarinic receptor activation: in vivo study. Eur J Neurosci 20:1267-1275. CrossRef Medline

Peebles CL, Yoo J, Thwin MT, Palop JJ, Noebels JL, Finkbeiner S (2010) Arc regulates spine morphology and maintains network stability in vivo. Proc Natl Acad Sci U S A 107:18173-18178. CrossRef Medline

Perez-Cruz C, Nolte MW, van Gaalen MM, Rustay NR, Termont A, Tanghe A, Kirchhoff F, Ebert U (2011) Reduced spine density in specific regions of CA1 pyramidal neurons in two transgenic mouse models of Alzheimer's disease. J Neurosci 31:3926-3934. CrossRef Medline

Plath N, Ohana O, Dammermann B, Errington ML, Schmitz D, Gross C, Mao X, Engelsberg A, Mahlke C, Welzl H, Kobalz U, Stawrakakis A, Fernandez E, Waltereit R, Bick-Sander A, Therstappen E, Cooke SF, Blanquet V, Wurst W, Salmen B, et al. (2006) Arc/Arg3.1 is essential for the consolidation of synaptic plasticity and memories. Neuron 52:437-444. CrossRef Medline

Ploski JE, Pierre VJ, Smucny J, Park K, Monsey MS, Overeem KA, Schafe GE (2008) The activity-regulated cytoskeletal-associated protein (Arc/Arg3.1) is required for memory consolidation of pavlovian fear conditioning in the lateral amygdala. J Neurosci 28:12383-12395. CrossRef Medline

Ramírez-Amaya V, Vazdarjanova A, Mikhael D, Rosi S, Worley PF, Barnes CA (2005) Spatial exploration-induced Arc mRNA and protein expression: evidence for selective, network-specific reactivation. J Neurosci 25: 1761-1768. CrossRef Medline

Reijmers LG, Perkins BL, Matsuo N, Mayford M (2007) Localization of a stable neural correlate of associative memory. Science 317:1230-1233. CrossRef Medline

Roberts TF, Tschida KA, Klein ME, Mooney R (2010) Rapid spine stabilization and synaptic enhancement at the onset of behavioural learning. Nature 463:948-952. CrossRef Medline

Rodriguez A, Ehlenberger DB, Hof PR, Wearne SL (2006) Rayburst sampling, an algorithm for automated three-dimensional shape analysis from laser scanning microscopy images. Nat Protoc 1:2152-2161. CrossRef Medline

Rodriguez A, Ehlenberger DB, Dickstein DL, Hof PR, Wearne SL (2008) Automated three-dimensional detection and shape classification of dendritic spines from fluorescence microscopy images. PLoS One 3:e1997. CrossRef Medline

Sanders J, Cowansage K, Baumgärtel K, Mayford M (2012) Elimination of dendritic spines with long-term memory is specific to active circuits. J Neurosci 32:12570-12578. CrossRef Medline

Santos HR, Cintra WM, Aracava Y, Maciel CM, Castro NG, Albuquerque EX (2004) Spine density and dendritic branching pattern of hippocampal CA1 pyramidal neurons in neonatal rats chronically exposed to the organophosphate paraoxon. Neurotoxicology 25:481-494. CrossRef Medline

Schacher S, Hu JY (2014) The less things change, the more they are different: contributions of long-term synaptic plasticity and homeostasis to memory. Learn Mem 21:128-134. CrossRef Medline

Schäfer MK, Eiden LE, Weihe E (1998) Cholinergic neurons and terminal fields revealed by immunohistochemistry for the vesicular acetylcholine transporter: I. Central nervous system. Neuroscience 84:331-359. CrossRef Medline

Shepherd JD, Rumbaugh G, Wu J, Chowdhury S, Plath N, Kuhl D, Huganir RL, Worley PF (2006) Arc/Arg3.1 mediates homeostatic synaptic scaling of AMPA receptors. Neuron 52:475-484. CrossRef Medline

Steckler T, Risbrough V (2012) Pharmacological treatment of PTSD: established and new approaches. Neuropharmacology 62:617-627. CrossRef Medline

Tayler KK, Lowry E, Tanaka K, Levy B, Reijmers L, Mayford M, Wiltgen BJ (2011) Characterization of NMDAR-independent learning in the hippocampus. Front Behav Neurosci 5:28. CrossRef Medline

Tayler KK, Tanaka KZ, Reijmers LG, Wiltgen BJ (2013) Reactivation of neural ensembles during the retrieval of recent and remote memory. Curr Biol 23:99-106. CrossRef Medline

Yang G, Pan F, Gan WB (2009) Stably maintained dendritic spines are associated with lifelong memories. Nature 462:920-924. CrossRef Medline

Yin Y, Edelman GM, Vanderklish PW (2002) The brain-derived neurotrophic factor enhances synthesis of Arc in synaptoneurosomes. Proc Natl Acad Sci U S A 99:2368-2373. CrossRef Medline

Zakharenko SS, Patterson SL, Dragatsis I, Zeitlin SO, Siegelbaum SA, Kandel ER, Morozov A (2003) Presynaptic BDNF required for a presynaptic but not postsynaptic component of LTP at hippocampal CA1-CA3 synapses. Neuron 39:975-990. CrossRef Medline 